\title{
Avances de Investigación
}

Empleo, productividad e innovación
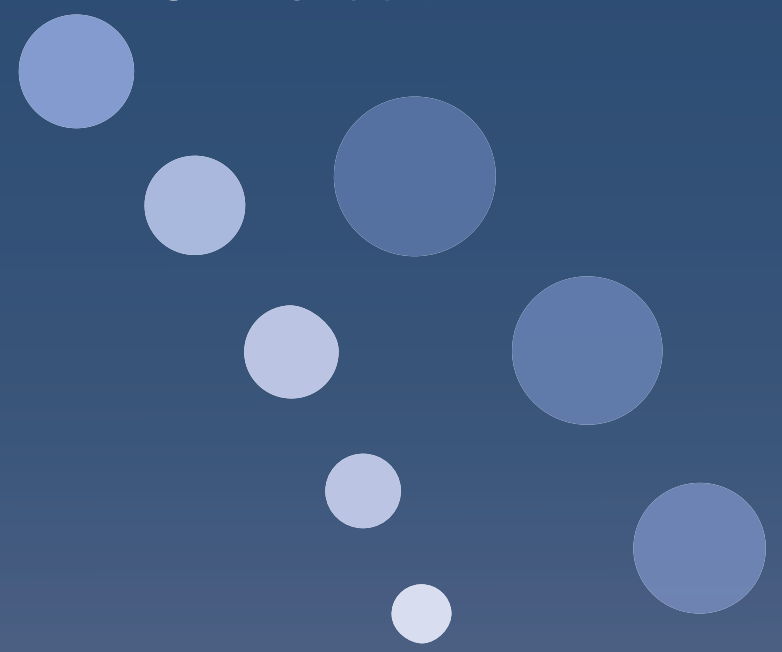

How do Latin American migrants in the U.S.

stand on schooling premium?

What does it reveal about education quality in their home countries?

Daniel Alonso-Soto Hugo Ñopo

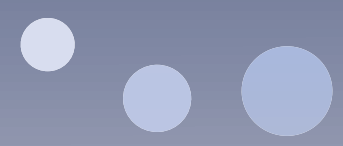



How do Latin American migrants in the U.S. stand on schooling premium?

What does it reveal about education quality in their home countries? 

Avances de Investigación 29

\title{
How do Latin American migrants in the U.S. stand on schooling premium? What does it reveal about education quality in their home countries?
}

\author{
Daniel Alonso-Soto \\ Hugo Nopo ${ }^{1}$
}

1 Alonso-Soto is a Labour Market Economist at Organization for Economic Co-operation and Development (OECD). Nopo is a Senior Researcher at Group for the Analysis of Development (GRADE).We would like to thank seminar participants at LACEA 2015 and RIDGE 2015 for useful comments and suggestions. 
GRADE's research progress papers have the purpose of disseminating the preliminary results of research conducted by our researchers. In accordance with the objectives of the institution, their purpose is to perform rigorous academic research with a high degree of objectivity, to stimulate and enrich the debate, design and implementation of public policies. The opinions and recommendations expressed in these documents are those of their respective authors; they do not necessarily represent the opinions of their affiliated institutions. The authors declare to have no conflict of interest related to the current study's execution, its results, or their interpretation. Most of the research of this paper was perform while the authors were at the Inter-American Development Bank. The publication, but not the research on which it was based, is funded by the International Development Research Centre, Canada, through the Think Tank Initiative.

Lima, September 2017

GRADE, Group for the Analysis of Development

Av. Almirante Grau 915, Barranco, Lima, Peru

Phone: (51-1) 247-9988

Fax: (51-1) 247-1854

www.grade.org.pe

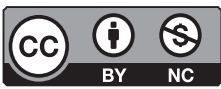

The work is licensed under a Creative Commons Attribution-NonCommercial 4.0 International

Research director: Santiago Cueto

Edition assistance: Diana Balcázar T.

Cover design: Elena González

Design of layout: Amaurí Valls M.

Print: Impresiones y Ediciones Arteta E.I.R.L Cajamarca 239 C, Barranco, Lima, Perú.

Phone: (51-1) 247-4305 / 265-5146 
Index

$\begin{array}{ll}\text { Abstract } & 7\end{array}$

Introduction 9

1. Methodology 13

2. Data and descriptive statistics $\quad 15$

3. Results 19

4. Controlling for non-random selection into migration 29

4.1. A diff-in-diff approach 31

4.2. By occupation 36

4.3. Non-parametric matching 38

5. Conclusions 43

References $\quad 45$

Appendix $\quad 49$ 

Indicators for quality of schooling are not only relatively new in the world but also unavailable for a sizable share of the world's population. In their absence, some proxy measures have been devised. One simple but powerful idea has been to use the schooling premium for migrant workers in the U.S. (Bratsberg and Terrell 2002). In this paper we extend this idea and compute measures for the schooling premium of immigrant workers in the U.S over a span of five decades. Focusing on those who graduated from either secondary or tertiary education in Latin American countries, we present comparative estimates of the evolution of such premia for both schooling levels. The results show that the schooling premia in Latin America have been steadily low throughout the whole period of analysis. The results stand after controlling for selective migration in different ways. This contradicts the popular belief in policy circles that the education quality of the region has deteriorated in recent years. In contrast, schooling premium in India shows an impressive improvement in recent decades, especially at the tertiary level.

JEL Codes: I26, J31, J61

Keywords: Schooling premium (returns to education), Wage differentials, Immigrant workers 

Education is critical for economic growth, poverty reduction, wellbeing, and a plethora of desirable social outcomes. The individual contribution of schooling has often been measured by labor market earnings. For almost five decades, researchers have examined the patterns of estimated schooling premia across economies. ${ }^{2}$ The premia are typically shown as the estimated proportional increase in an individual's labor market earnings for each additional year of schooling completed.

However, there are two main reasons as to why researchers are limited in their comparisons of this expansive empirical literature: differences in data sample coverage and methodology. First, survey samples may not accurately reflect population distributions. For cost or convenience, surveys may concentrate on subpopulations that are easier or less expensive to reach, focus on firms rather than households, or concentrate on urban populations while excluding rural residents. Second, studies rarely use the same model to estimate returns. Variation in the control variables used in the models can affect estimated returns, as can variation in the used estimation strategy (Psacharopoulos and Patrinos 2004).

2 Mincer (1974), Psacharopoulos (1972, 1973, 1985, 1989, 1994), Harmon et al. (2003), Heckman et al. (2003), Psacharopoulos and Patrinos (2004), Banerjee and Duflo (2005), Colclough et al. (2010), Psacharopoulos and Layard (2012), Montenegro and Patrinos (2014). 
In this paper, we overcome both sources of non-comparability by focusing on a single economy (the U.S.), a sequence of the same survey instrument (the population census), and the same regression analysis during a period that comprises five decades. Along the lines of Bratsberg and Terrell (2002), we explore labor earnings differentials for immigrant workers in the U.S. by presenting comparable estimates of the schooling premium at the secondary and tertiary levels of education for individuals who were educated in their home country.

The analysis of immigrant workers in the U.S. is not new. The resurgence of large-scale immigration sparked the development of an extensive literature that examines the performance of immigrant workers in the labor market, including their earnings upon entry and their subsequent assimilation toward the earnings of native-born workers (see Borjas 1999 and LaLonde and Topel 1997, for surveys). An important finding of this literature is that, over the period 1960-1990, there was a continuous decline in the relative entry wage of new immigrants. This is true in terms of both unadjusted earnings and earnings conditional upon characteristics such as education and experience. Borjas (1992) and Borjas and Friedberg (2009) show that there was a decline in cohort quality between 1960 and 1980, and this pattern was reversed during the 1990s. Most of these fluctuations can be explained by a shift in the origin-country composition of immigration to the United States. Following the 1965 Amendments to the Immigration and Nationality Act, fewer immigrants originated in Europe. Instead, the majority came from developing countries, particularly Latin American and Asia. Immigrants from these countries tended to be less skilled and had worse outcomes in the U.S. labor market than immigrants from other regions. Hanushek and Kimko (2000) find that this can be explained by the immigrants' home-country education quality. For immigrants who are educated in their own country but not in the United 
States, the quality of education in their country of origin is directly related to U.S earnings.

Similar to the methodological approach of this paper, Bratsberg and Terrell (2002) focus on the U.S. labor markets and investigate the influence of the country of origin on the schooling premium of immigrants. In particular, they link the schooling premium to the school quality of the countries of origin. They show that immigrants from Japan and Northern Europe receive high returns and immigrants from Central America receive low returns. Similarly, Bratsberg and Ragan (2002) find significant earnings differentials between immigrants that acquired schooling in the U.S. and those that did not. Hanushek and Woessmann (2012a) provide new evidence about the potential causal interpretation of the cognitive skills-growth relationship. By using more recent U.S. data, they were able to make important refinements to the analysis of cognitive skills on immigrants' labor market earnings that were previously introduced in Hanushek and Kimko (2000). They also included the specification of full difference-in-differences models that we will use in this paper.

Hanushek and Woessmann (2012b) use a new metric for the distribution of educational achievement across countries, which was introduced in Hanushek and Woessmann (2012a), to try and solve the puzzle of Latin American economic development. The region has trailed most other world regions over the past half century despite relatively high initial development and school attainment levels. This puzzle, however, can be resolved by considering educational achievement, a direct measure of human capital. They found that in growth regressions, the positive growth effect of educational achievement fully accounts for the poor growth performance of Latin American countries. These results are confirmed in a number of instrumental-variable specifications that exploit plausible exogenous achievement variations, 
which stem from historical and institutional determinants of educational achievement. Finally, a development accounting analysis finds that, once educational achievement is included, human capital can account for between half to two-thirds of the income differences between Latin America and the rest of the world.

In this paper we also focus on the schooling premia for the Latin American and the Caribbean region (LAC) and compare them to those of migrants from other regions, particularly from East Asia and Pacific (EAP), India, Northern Europe, and Southern Europe, all relative to immigrants from former Soviet Republics. ${ }^{3}$ The available data allows us to measure such premia for workers who graduated from school, either at the secondary or tertiary levels, in their home countries between 1940 and 2010.

The rest of the paper proceeds as follows. The next section contains a description of the methodology. In section 3 we introduce the data sources and some descriptive statistics that compare immigrants educated in their country of origin versus immigrants educated in U.S. by census year and region of origin. Section 4 presents estimates of the schooling premium (secondary and tertiary) for male immigrants from 17 LAC countries and 4 other regions relative to male immigrants from the former Soviet Republics. Section 5 examines the robustness of results after controlling for non-random migration, and section 6 concludes.

3 Table A1 in the appendix lists the countries included in each region. 
Mincer (1974) has provided a great service in estimating the schooling premium by means of the semi-log earnings function. The now standard method of estimating private benefits per year of schooling is by determining the log earnings equations with the form:

$$
\ln \left(w_{i}\right)=\alpha+\beta_{1} E D U C_{i}+\beta_{2} \mathrm{Age}_{i}+\beta_{3} \mathrm{Age}_{i}^{2}+\beta_{4} X_{i}+\mu_{i}
$$

where $\ln \left(w_{i}\right)$ is the natural $\log$ of hourly earnings for the $i$ th individual; $E D U C_{i}$ is years of schooling (as a continuous variable); Age $_{i}$ is the age of the individual; $X_{i}$ is a set of control variables, and $\mu_{i}$ is a random disturbance term reflecting unobserved characteristics. The set of control variables $X_{i}$ is kept deliberately small to avoid overcorrecting for factors that are correlated with years of schooling. In this way $\beta_{1}$ can be interpreted as the average premium per year of schooling.

In this paper, we are also interested in the schooling premium received by immigrant workers in the U.S who graduated from school during the last five decades. For this purpose, we add a set of dummy variables $\mathrm{D}$ which account for the country of origin of all workers. Additionally, we use a linear-spline specification where EDUC appears in two segments: years greater than 8 and less than or equal to 12 (secondary education) and years greater than 12 (tertiary education) to allow for a nonlinear fit. As a result, the main equation to estimate is: 


$$
\begin{gathered}
\ln \left(w_{i j t}\right)=\alpha+\beta_{1} \mathrm{D} * \mathrm{EDUC}_{i}+\beta_{2} E D U C_{i}+ \\
\beta_{3} A_{g e_{i t}}+\beta_{4} A g e_{i t}{ }^{2}+\beta_{5} X_{i j t}+\mu_{j t}+\varepsilon_{i t}
\end{gathered}
$$

Now, $\ln \left(w_{i j t}\right)$ is the natural log of hourly earnings for the $i$ th individual graduated in cohort year $t$. The vector of control variables $\mathrm{X}$ contains the following variables: a set of dummy variables for English proficiency (speaks English well, very well or native), a dummy for marital status (married with spouse present), eight census divisions, years in the United States as a control for assimilation, and the average growth in GDP per capita of the country of origin during the five years prior to immigration in the US to control for economic conditions. The error tem of the wage regression consists of a country-specific component $(\mu)$ and an individual component $(\varepsilon)$.

First, we focus on workers who acquired all their education outside the U.S. The estimate of the country-of-birth's specific schooling premium is the coefficient of the interaction term between the country-specific dummy variable and years of (secondary or tertiary) schooling of the individual. The omitted level is immigrants from former soviet republics ${ }^{4}$ (with secondary or tertiary schooling). In this way $\beta_{1}$, the premium per year of schooling, can be estimated for each country of origin for different levels of schooling.

Such set of coefficients $\beta_{1}$ can also be interpreted as the "first differences" in schooling premia between migrants from different countries/regions (vis-a-vis those of migrants that are in the base category) for different schooling levels. We closely follow this approach, which was introduced by Bratsberg and Terrell (2002), to make our estimations in section 4. Later in section 5, we will introduce different ways of controlling for non-random selection into migration.

4 Pooled of immigrants from: Albania, Armenia, Bulgaria, Czech Republic, Estonia, Hungary, Latvia, Lithuania, Macedonia, Moldova, Poland, Romania, Russian Federation and Slovak Republic. 


\section{DATA AND DESCRIPTIVE STATISTICS}

We use a pooled data set from the Public Use Microdata for the 19802000 U.S. Censuses 5\% sample and the American Community Survey 2008-2012 5-Year sample. ${ }^{5}$ The analysis is restricted to men aged 25-64 currently working and not in school, with incomes more than $\$ 1,000$ a year, who have worked 50 weeks or more during the last year ${ }^{6}$, and have worked more than 30 hours during the last week. Hourly earnings are calculated from the annual wage and salary income divided by weeks worked per year, which is then divided by hours worked per week. All earnings are in 1999 dollars. We complement this with additional data from the World Bank national accounts data and OECD National Accounts data files for information on GDP growth.

Following Jaeger's method (1997), we convert educational attainment to years of schooling using the following rule: ${ }^{7}$ years of schooling equals zero if educational attainment is less than first grade; 2.5 if first through fourth grade; 5.5 if grade fifth or sixth grade; 7.5 if grade seventh or eighth grade; educational attainment if ninth through twelfth grade; 12 if GED earned; 13 if some college, but no degree; 14 if associate degree earned; 16 if bachelor's degree earned; 18 if master's degree

5 The ACS 2008-2012 is a 5\% random sample of the population and contains all households and persons from the 1\% ACS samples for 2008, 2009, 2010, 2011 and 2012, identifiable by year.

6 In the ACS (2008-2012) the number of weeks is reported in intervals so to keep comparability throughout the different sources we impose this restriction. More than $80 \%$ of the sample meets this requirement.

7 See Jaeger (1997) for a discussion of alternate conversion rules. 
earned; 19 if professional degree earned; and 20 if doctorate degree earned ${ }^{8}$. Finally, as mentioned in the methodology section, we split the years of schooling variable intro three categories - years of primary, secondary and tertiary schooling.

Non-citizens and naturalized citizens are labeled as "immigrants". All others are classified as "natives." "Immigrants educated in origin" are defined as those whose final year of graduation is before their year of immigration. "Immigrants educated in the U.S." are defined as those who arrived to the U.S. with six or fewer years of education in their origin country and continued their education within the U.S. We exclude persons from the regression sample if we cannot identify which group they belong to.

Table 1 shows descriptive statistics for relevant variables. We can observe some differences between regions and some general trends over time. Regarding education, the other regions clearly have a much larger proportion of immigrants with tertiary education than LAC. The fact that LAC immigrants are less educated is reflected by the fact that a much larger proportion of Latin American workers are in blue collar occupations. As expected, the main trend observed over time is the increase in the levels of education of all immigrants. On the other hand, the increase in the access to secondary education of LAC immigrants is particularly remarkable. Less than $27 \%$ of immigrants from LAC who graduated in the 40's or 50's had secondary education, and now more than $68 \%$ of recent Latin American graduated immigrants have reached that level.

8 Due to differences in the educational attainment variable, in the 1980 census data we convert educational attainment to years of schooling using the following rule: years of schooling equals zero if educational attainment is less than first grade; 1 year per grade (grades 1 through 12), i.e. 1 year if finished 1 st grade, 2 if finished 2 nd grade and so on and so forth; and finally years of schooling equals 14 if 4 years of college and adds 1 year per additional year of college up to 17 if has 8 years of college. 


$$
1
$$



Table 2 shows results for the regressions that estimate equation (2). In the table we combine results for four world regions (East Asia and Pacific, India, Northern Europe and Southern Europe) and seventeen countries from Latin America and the Caribbean. In each pair of columns, we report the results for a pooled set of immigrants by graduation cohorts (1940-59, 1960-69, 1970-79, 1980-89 or 19902010). We report only the coefficient of interest, $\beta_{1}$, the difference in schooling premia between each country/region and the base category. This schooling premia is for every year of education. As outlined in equation (2), we allow such schooling premia to vary between levels (secondary and tertiary). In addition to tables with the estimated coefficients and with a visual purpose, we also compute the parameter estimates over a rolling window of a fixed size ${ }^{9}$ through the sample, so we can get smooth time-varying parameters and plot them against the year of graduation ${ }^{10}$ of immigrants as time variable.

Regarding migrants with only high school studies, the most salient fact is that most of the countries in Latin America show stagnancy or decline in the evolution of their schooling premium relative to those of other immigrants (figure 3). For other regions of the world, the

921 years (leaving 10 years behind and 10 years ahead) when using global regions and 31 (15 and 15) when estimating the parameters for LAC countries.

10 Because the questionnaire does not ask the year of graduation of the individual, we infer year of graduation as year of birth plus six plus years of schooling. 
evolution has been somewhat different. The schooling premium of immigrants from southern Europe begun to grow in mid-70's and started to fall in the early 90 's. Immigrants from both India and East Asian and the Pacific show a schooling premium that originally was lagging behind than those from LAC, but now the situation is reversing.

Within Latin America and the Caribbean, it is interesting to note that the southern cone countries have the highest premium but showing a negative tendency. From the mid-40's until the early 70 's Central American countries showed a temporary improvement. The case of Cuba is interesting as it is the only country with constant improvements in their relative schooling premium since the early 60's. However, most of the countries show a stagnation or even a decline in schooling premium, although some countries such as Brazil and to a lesser extent the Andean countries at least seem to show an improvement in their premia since the mid- 80 's,

For migrants with tertiary studies in their home country the situation is somewhat different. All in all, the Latin American relative schooling premium is even worse than the one reported for secondary, falling behind from other regions relative to other immigrants premium (figure 4). Whereas all regions' premia, except India, remain stagnated for the period, Latin America and the Caribbean premia show a clear decline, widening the gap with other regions. India's schooling premium in tertiary education has been consistently increasing since the late 70's, showing the highest increase. Within Latin America and the Caribbean, only the southern cone shows positive schooling premium, although the Andean region had positive premium for those graduated in the 50's. By country, in Central America and in the Caribbean, there seem to be two clear groups of countries within those regions. In central America, Costa Rica and Panama clearly show higher premia than their peers in the region (figure 6) and in the Ca- 
ribbean, Jamaica and Trinidad and Tobago over perform their Spanish speaking neighbors (Cuba and Dominican Republic) even though we are controlling for English proficiency. Overall, all countries in the region show either a stagnancy or a clear decline in their tertiary premia over the past decade, raising a flag and should be cause of concern on how Latin American immigrants education is rewarded in the US. 


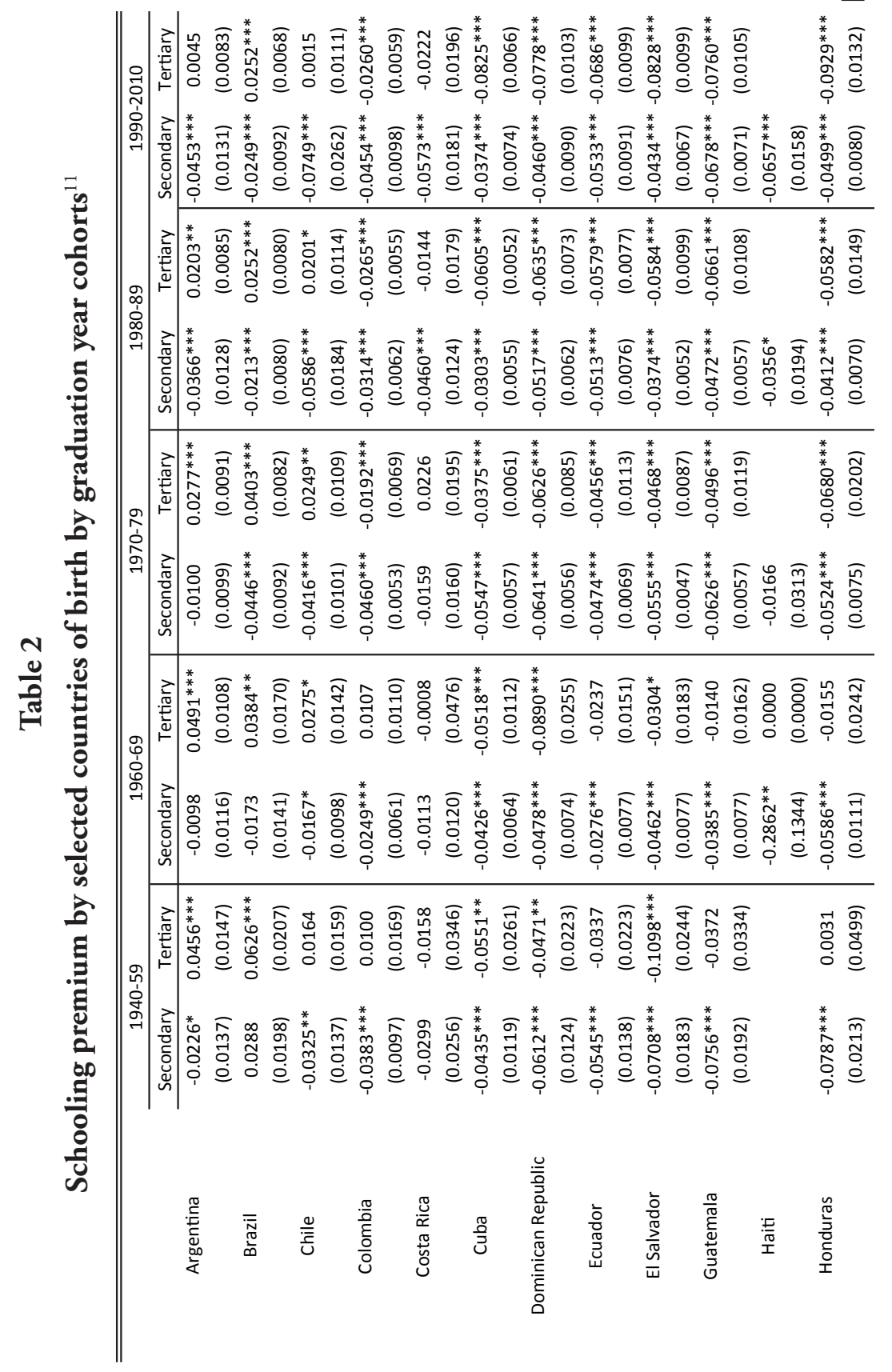




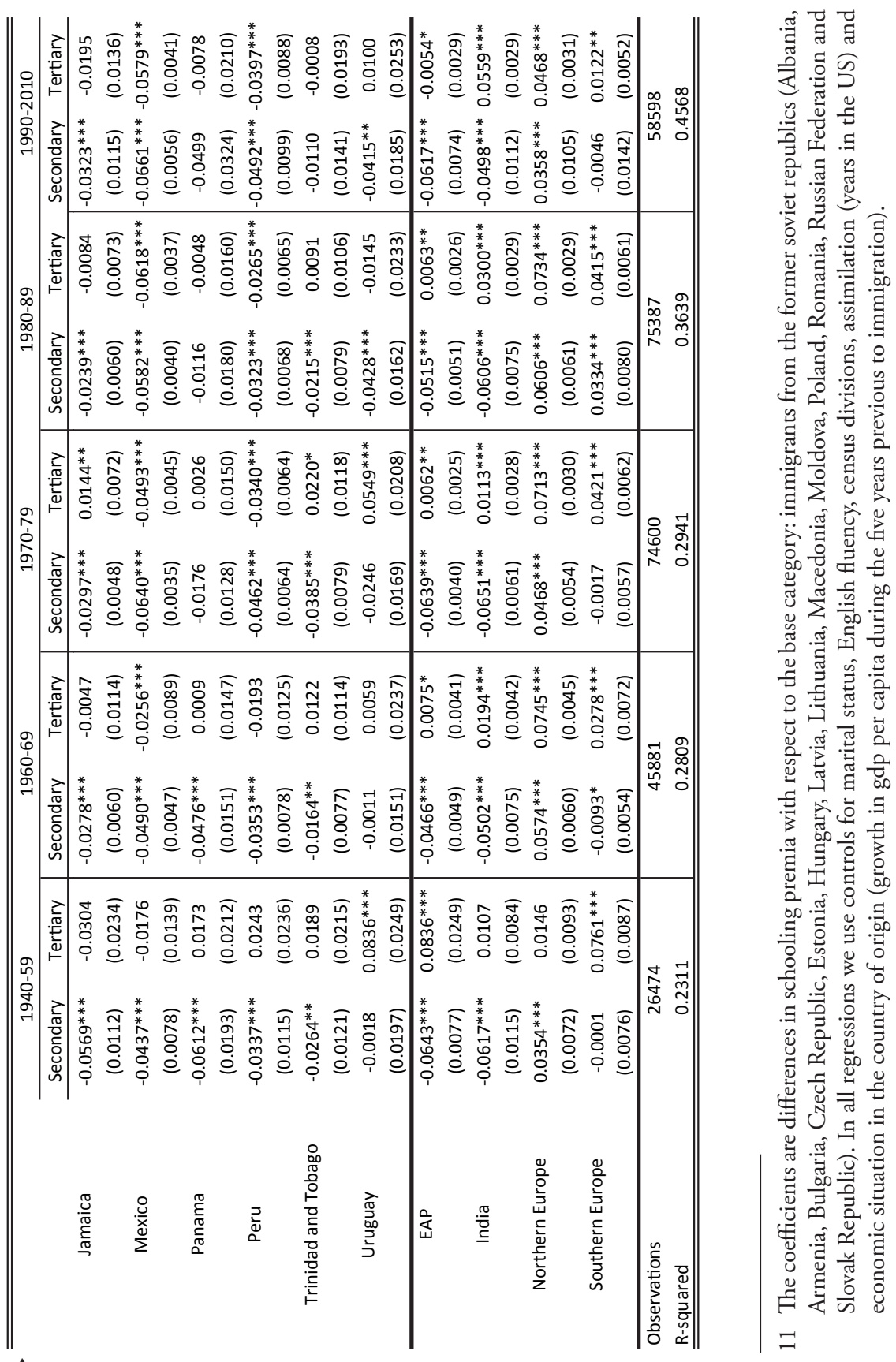




\section{Figure 1}

\section{Evolution of secondary schooling premium relative to other ${ }^{12}$ immigrants by global regions}

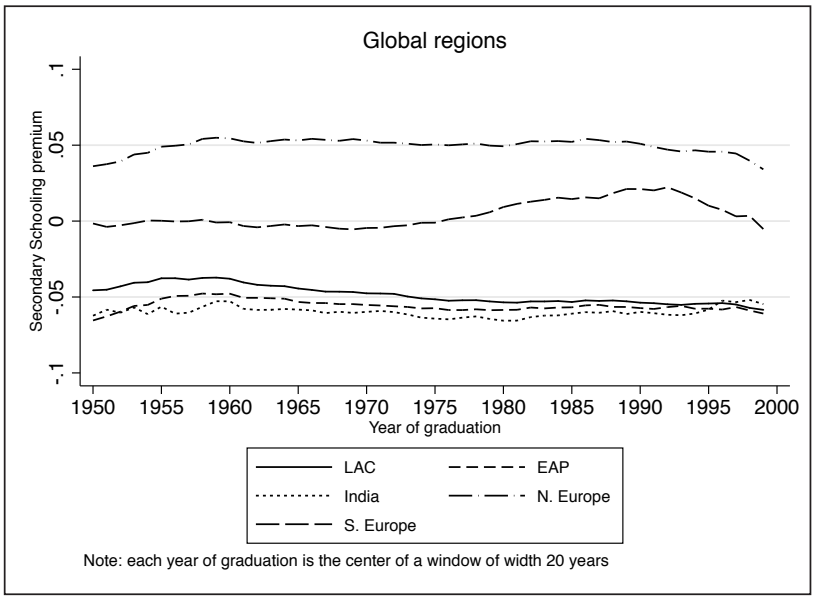

\section{Figure 2}

\section{Evolution of secondary schooling premium relative} to other immigrants by LAC regions

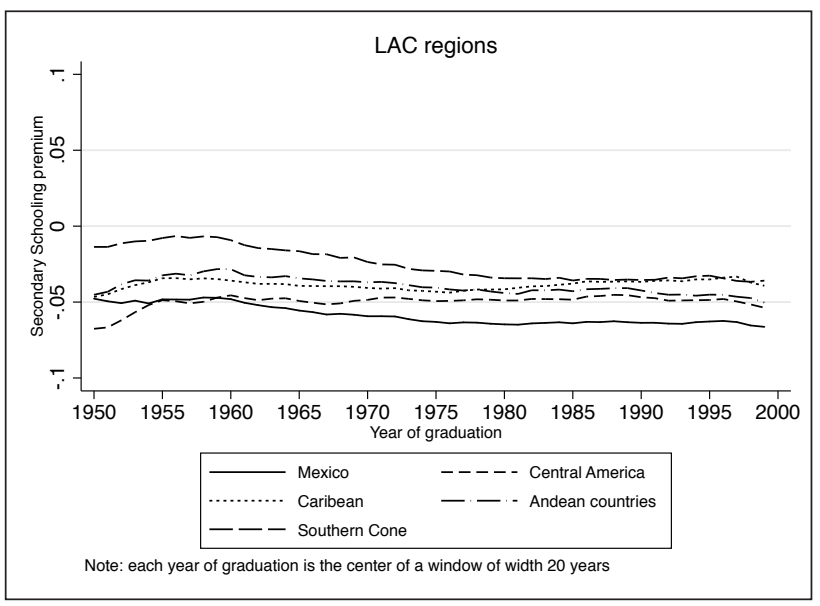

12 Pooled of immigrants from: Albania, Armenia, Bulgaria, Czech Rep., Estonia, Hungary, Latvia, Lithuania, Macedonia, Moldova, Poland, Romania, Russian Fed. and Slovak Rep. 
Figure 3

\section{Evolution of secondary schooling premium relative} to other immigrants by LAC countries

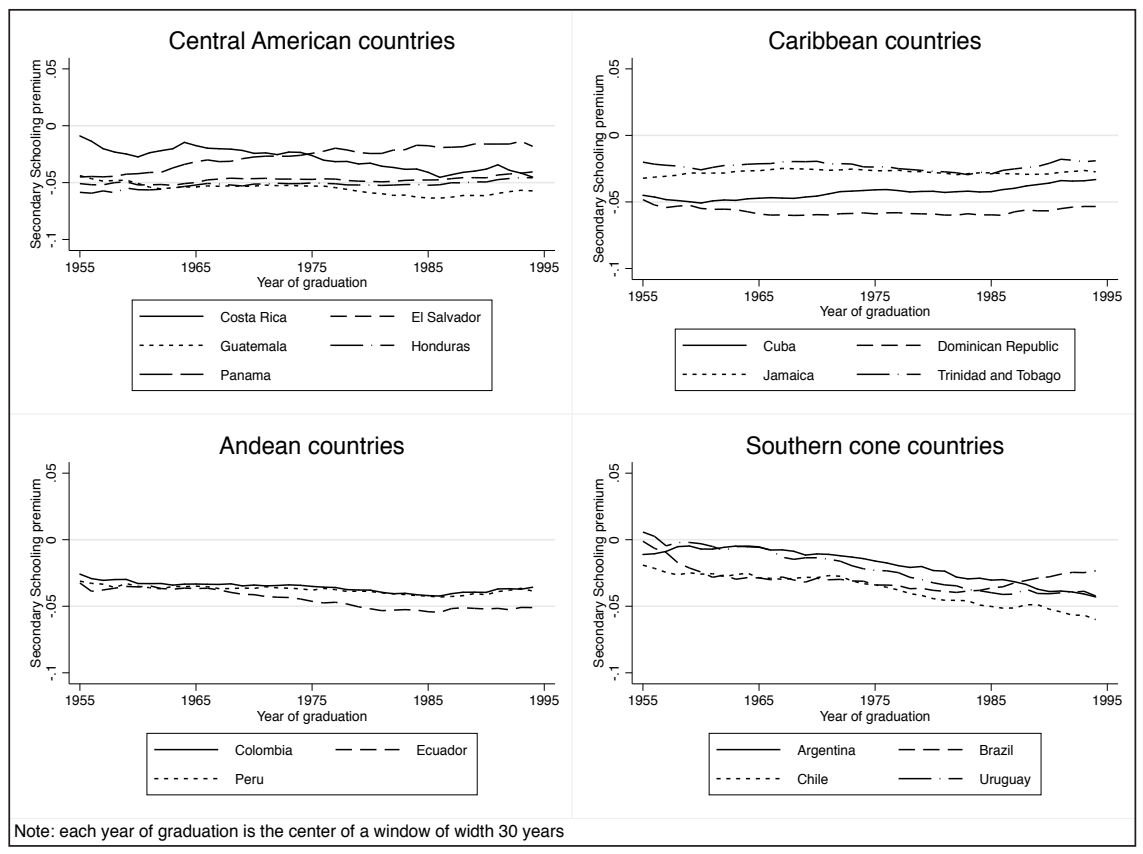


Figure 4

Evolution of tertiary schooling premium relative to other immigrants by global regions

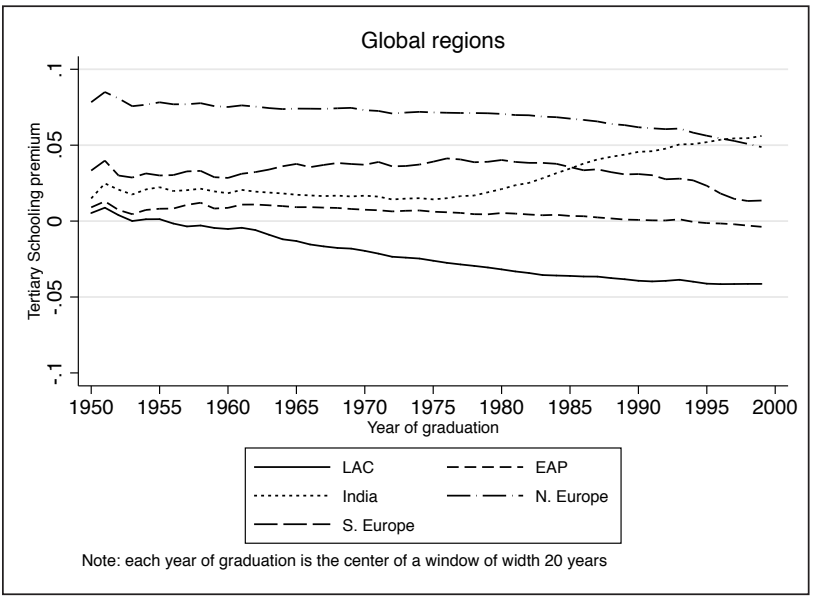

Figure 5

Evolution of tertiary schooling premium relative to other immigrants by LAC regions

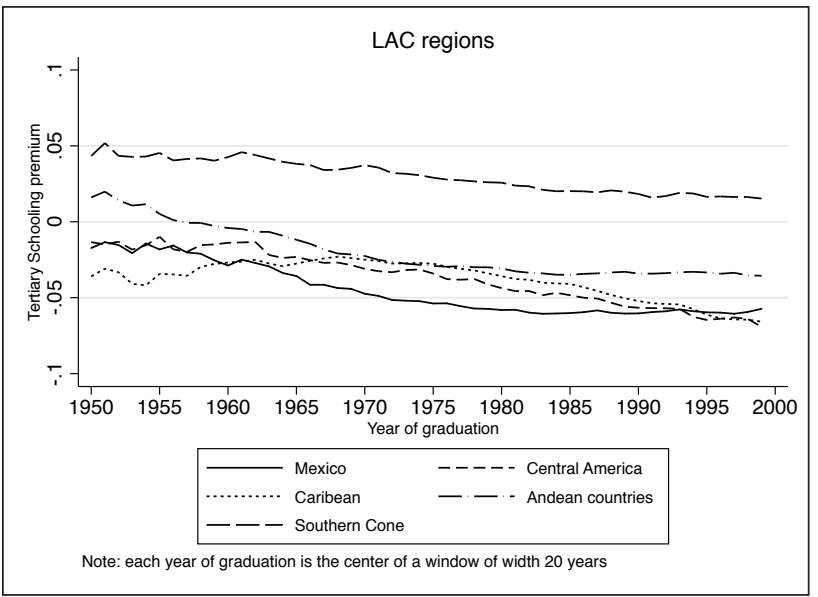


Figure 6

\section{Evolution of tertiary schooling premium relative to other immigrants by LAC countries}

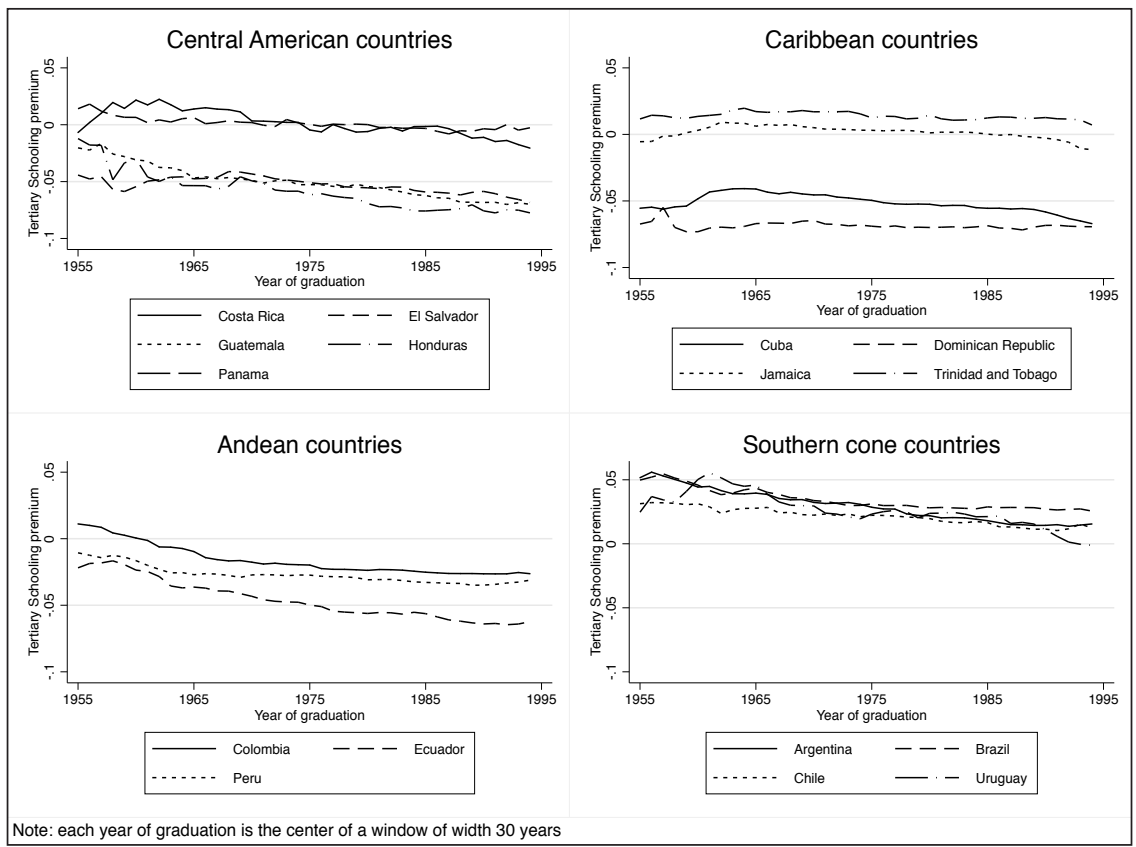





\section{CONTROLLING FOR NON-RANDOM SELECTION INTO MIGRATION}

Migrants in the U.S. are not a random sample of the populations of their corresponding countries of origin. Self-selection into emigration as well as into a subsequent non-return to their home countries occurs both in observable and unobservable characteristics (Borjas 1987, Borjas and Bratsbert 1996). Figure A1 in the appendix shows that this is the case for years of schooling when comparing the data for migrants (from the U.S. Census) and that of populations in the home countries (from the Barro and Lee data sets). Immigrants are selected on various characteristics in addition to education, such as occupations, skills, age, gender, ambitions, and other hard-to-observe traits. The selection process occurs on several complex and interrelated ways and such selectivity could bias our estimators of schooling premia.

Furthermore, the literature suggests that the degree to which immigrants differ in education from nonimmigrants in their homelands varies by source country. Even if immigrants are all positively selective (in the sense that their characteristics are linked to higher labor earnings), there may be substantial variability in the level of selectivity by origin country. There are various factors for these variations. First, migrants from more-educated populations may be less positively selective, since the possibility that they have more schooling than the average person in their home country is not high. Additionally, migrants from countries which are further from the United States should be more highly selective because there are greater costs associated with 
migrating long distances. And according to Lee (1966), migrants who respond to push factors will be less selective. Economists have also assumed that selectivity applies only to economic migrants (Chiswick 2000).

Figure A1 in the appendix shows that all immigrants in our sample are positively selective and there is substantial variability in the level of selectivity by origin country. In general, immigrants from LAC countries seem to be less positively selective than immigrants from other regions. Immigrants from Mexico and other countries from Central America are less educationally selective, whereas those from the Southern cone and Asia are more. In particular, selection for immigrants from India seems to be high, supporting the idea that migrants from countries that are farther from the United States should be more highly selective.

Another source of selection might stem from the occupations that immigrants ending up working in the United States. As figure A2 show, the proportion of immigrants working in white and blue collar occupations varies considerably across cohorts within the same country, reflecting the changes in the mix of occupations in the U.S labor force. Although the shift from a labor force composed of mostly manual laborers to mostly white collar and service workers could be observed from the beginning of the 20th century, a notable acceleration of this trend occurred in the 1980s and is still growing. Even though this trend can be observed for most countries, there are some countries, particularly immigrants from Mexico, Central America and to a lesser extent from the Caribbean that are still employed mainly in blue collar occupations probably reflecting that immigrants from those countries are less educational selective as we mentioned previously.

Finally, it's worth mentioning that as expected, the number of immigrants vary by country, but also by cohort from a same country. 
Figure A3 shows the waves of immigrants by selected regions. As expected, Mexico is by large the main country of origin of immigrants, and there is a clear decline in the number of immigrants for recent cohorts, being in general the most populous cohorts those graduated between 1970 and 1990 .

In this section we address the selection issue with three different approaches: a diff-in-diff setup, occupation-restricted regressions, and a non-parametric matching tool ${ }^{13}$.

\subsection{A diff-in-diff approach}

Table 3 shows the same descriptive statistics but for immigrants educated in the US and US natives. The first obvious difference with respect to the sample of immigrants educated in their country of origin is the limited number of observations, especially for the first few censuses. Additionally, we have a much younger sample for the first few censuses. Most of immigrants who migrated with less than six years of education in their countries of origin were less than 34 yearsold at the time of the census. In the following censuses, this particular sample becomes more evenly distributed in regards to age but still younger than the immigrant sample educated in their countries of origin. Finally, this sample is more educated than their counterparts who were educated in their countries of origin.

We introduce a refinement to equation (2) along the lines of Hanushek and Woessmann (2012a). This takes into consideration that the unobserved component may contain information about certain

13 In this section due to limitations in the number of observations, we perform the analysis using only region level aggregated data and 4 pooled sets of immigrants by graduation year $(<=1969,1970-1979,1980-89$ and 1990-2010). 


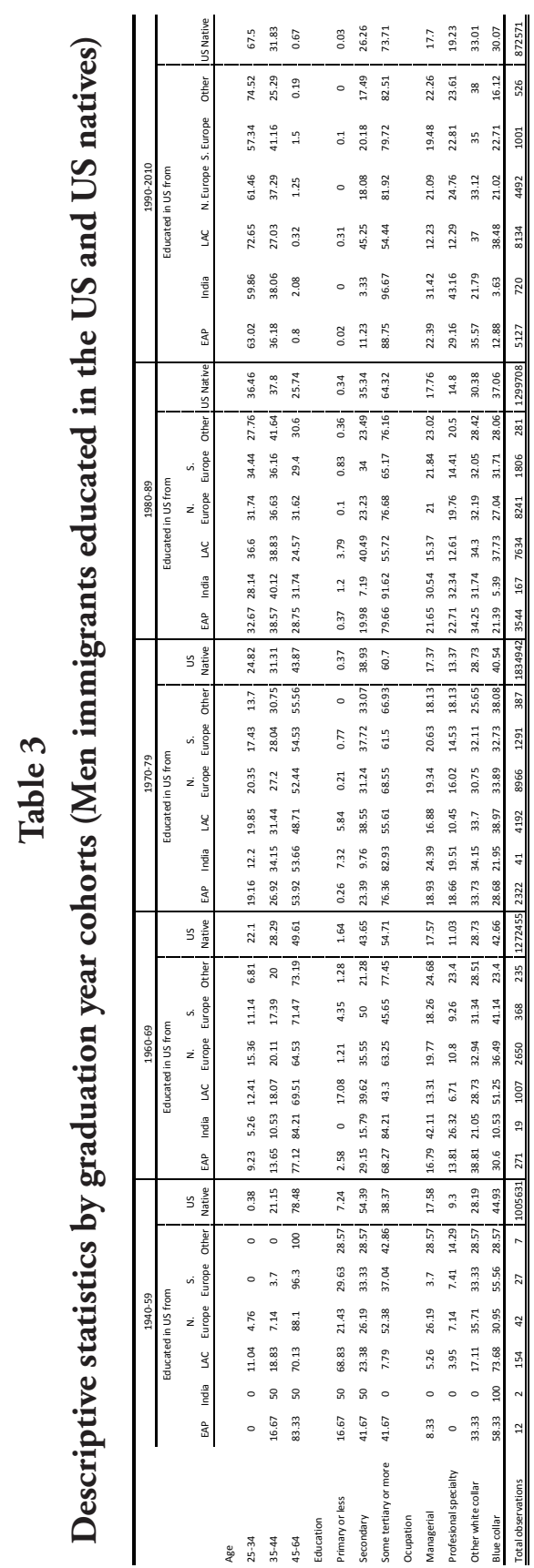


traits that are shared by all migrants originating from certain areas, such as work ethics, perseverance, attitudes, etc. If it were the case that these characteristics are ingrained in the populations from certain areas, it is not necessarily the case that these are the "results" of their educational systems.

Fortunately, there is a nice way to clean the results for these unobservable characteristics. To do this, we introduce a new group of workers, also migrants, but with differences in their place of education. These migrant workers are second generation immigrants who received their education in the U.S. By using their information with a "differences-in-differences" setup, we are able to clean the results from the unobservable factors/values that are nurtured in the original local societies and stay fixed after migration. Thus, we first follow a difference-in-differences strategy, comparing the returns of schooling for immigrants educated in their country of origin to those of immigrants from the same country educated within the United States. The equation of estimation (based on 2) is:

$$
\begin{aligned}
& \ln \left(w_{i j t}\right)=\alpha+\beta_{1} \mathrm{D} * E D U C_{i} * \mathrm{O}+\beta_{2} \mathrm{D}^{*} E D U C_{i}+ \\
& \beta_{3} E D U C_{i} * \mathrm{O}+\beta_{4} A g e_{i t}+\beta_{5} A_{g e_{i t}}{ }^{2}+\beta_{6} X_{i j t}+\mu_{j t}+\varepsilon_{i t}
\end{aligned}
$$

The parameter $\beta_{1}$ captures the relevant contrast in skills between home-country schooling and U.S. schooling ${ }^{14}$. We interpret $\beta_{1}$ as a difference-in-differences estimate of the effect of home-country schooling on earnings, where the first difference is between home-country

14 The assignment of individuals to U.S. schooling is based on census data indicating immigration before age 6 . The assignment of individuals to schooling all in country of origin is based on age of immigration greater than years of schooling plus six. A person who moves back and forth during the schooling years could be erroneously classified as all U.S. or no U.S. schooling, even though they are really in the partial treatment category (which is excluded from the difference-in-differences estimation). 
educated immigrants (the "treatment group") and U.S.-educated immigrants (the "control group") from the same country, and the second difference is in the average years of schooling of the home country. The parameter $\beta_{2}$ captures the bias that would emerge in standard crosssectional estimates from omitted variables like cultural traits that are correlated with home-country years of schooling in the same way for all immigrants from the same country of origin (independent of where they were educated).

The results previously reported remain after using the diff in diff methodology. The schooling premium for Latin America and the Caribbean is stagnated. In tertiary, again, Latin America and the Caribbean shows the lowest premium but now the decline trend seems to be reversed since the late 80 's, catching up with East Asian and the Pacific although still far from the other regions. In fact, the gap is widening with respect to India, since its impressive positive trend stands.

Table 4

Schooling premium by selected regions by graduation year cohorts (Diff in Diff specification)

\begin{tabular}{|c|c|c|c|c|c|c|c|c|}
\hline & \multicolumn{2}{|c|}{$<=1969$} & \multicolumn{2}{|c|}{ 1970-79 } & \multicolumn{2}{|c|}{ 1980-89 } & \multicolumn{2}{|c|}{ 1990-2010 } \\
\hline & Secondary & Tertiary & Secondary & Tertiary & Secondary & Tertiary & Secondary & Tertiary \\
\hline EAP & $\begin{array}{c}-0.0509 * * * \\
(0.0168)\end{array}$ & $\begin{array}{c}-0.0105 \\
(0.0232)\end{array}$ & $\begin{array}{c}-0.0537^{* * *} \\
(0.0119)\end{array}$ & $\begin{array}{c}-0.0352^{* * *} \\
(0.0097)\end{array}$ & $\begin{array}{l}-0.0545 \\
(0.0352)\end{array}$ & $\begin{array}{c}0.0029 \\
(0.0334)\end{array}$ & $\begin{array}{c}-0.0208 \\
(0.0171)\end{array}$ & $\begin{array}{c}-0.0068 \\
(0.0087)\end{array}$ \\
\hline India & $\begin{array}{c}0.0131 \\
(0.0518)\end{array}$ & $\begin{array}{c}0.0417 \\
(0.0319)\end{array}$ & $\begin{array}{c}-0.0299 \\
(0.0647)\end{array}$ & $\begin{array}{c}0.0083 \\
(0.0489)\end{array}$ & $\begin{array}{c}-0.1263^{* *} \\
(0.0639)\end{array}$ & $\begin{array}{c}0.0075 \\
(0.0355)\end{array}$ & $\begin{array}{l}-0.0615^{*} \\
(0.0328)\end{array}$ & $\begin{array}{c}0.0406^{* * *} \\
(0.0098)\end{array}$ \\
\hline LAC & $\begin{array}{l}-0.0018 \\
(0.0124)\end{array}$ & $\begin{array}{c}0.0177 \\
(0.0215)\end{array}$ & $\begin{array}{l}-0.0202^{*} \\
(0.0106)\end{array}$ & $\begin{array}{c}-0.0478^{* * *} \\
(0.0101)\end{array}$ & $\begin{array}{l}-0.0384 \\
(0.0347)\end{array}$ & $\begin{array}{c}-0.0234 \\
(0.0335)\end{array}$ & $\begin{array}{l}-0.0024 \\
(0.0156)\end{array}$ & $\begin{array}{l}-0.0067 \\
(0.0089)\end{array}$ \\
\hline Jorthern Europe & $\begin{array}{c}0.0552^{* * *} \\
(0.0104)\end{array}$ & $\begin{array}{c}0.0802^{* * *} \\
(0.0181)\end{array}$ & $\begin{array}{c}0.0615^{* * *} \\
(0.0107)\end{array}$ & $\begin{array}{c}0.0340^{* * *} \\
(0.0092)\end{array}$ & $\begin{array}{c}0.0475 \\
(0.0351)\end{array}$ & $\begin{array}{c}0.0786 * * \\
(0.0333)\end{array}$ & $\begin{array}{c}0.0787^{* * *} \\
(0.0184)\end{array}$ & $\begin{array}{c}0.0621 * * * \\
(0.0089)\end{array}$ \\
\hline Southern Europe & & & & & $\begin{array}{l}-0.0060 \\
(0.0357)\end{array}$ & $\begin{array}{c}0.0342 \\
(0.0341)\end{array}$ & $\begin{array}{c}0.0123 \\
(0.0222)\end{array}$ & $\begin{array}{c}0.0267^{* *} \\
(0.0108)\end{array}$ \\
\hline Ivatio & 764 & & 872 & & 873 & & 782 & \\
\hline R-squared & 0.2 & 559 & 0.29 & 901 & 0.3 & & 0.4 & 301 \\
\hline
\end{tabular}




\section{Figure 7}

Evolution of secondary schooling premium relative to other immigrants by global regions (Diff in Diff specification)

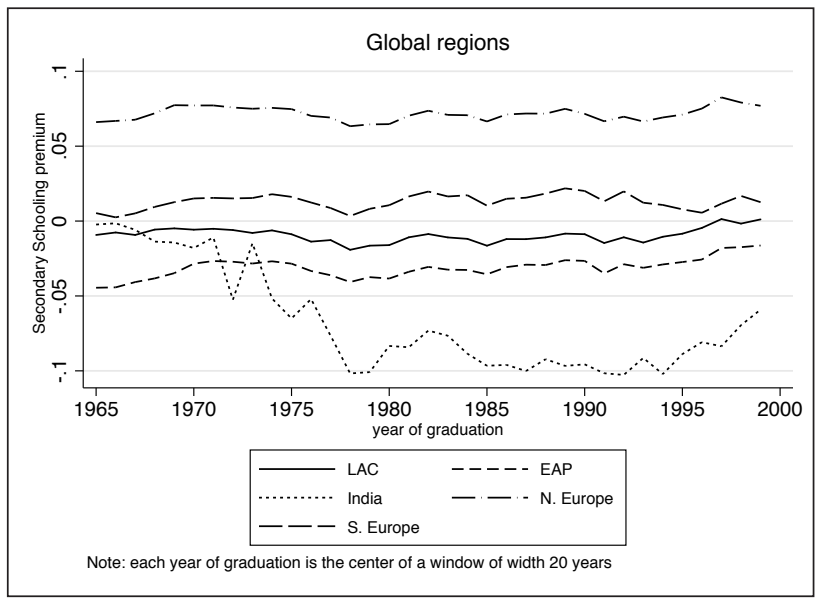

Figure 8

Evolution of tertiary schooling premium relative to other immigrants by global regions (Diff in Diff specification)

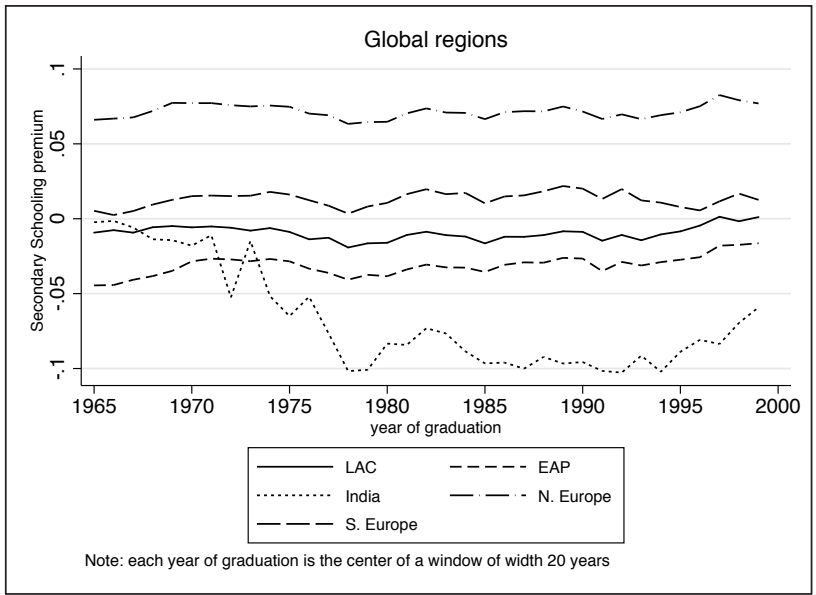




\subsection{By occupation}

What can explain the remarkable performance of India and the poor one in Latin America and the Caribbean? In this section we explore a possible additional way of selective migration: by occupations. We divide the sample of immigrant workers in four occupational groups: managerial, professional specialties, other white collars and blue collars ${ }^{15}$. In all four occupational groups in tertiary, Latin America and the Caribbean shows the lowest schooling premia. The impressive performance of India, in contrast, is still present in all but one occupational group: among blue collars the improvement of the schooling premium is not so marked, even there is also a positive trend for recent cohorts. However, it's for specialized professionals (doctors, engineers, architects, etc.) and for other white collars, most of the jobs related to new technologies (telecommunications, computers, etc.) are included in this category, where the increase in premia compared to other immigrants has been even more remarkable. This goes in line with the idea that the selective migration of Indian workers to the US emphasized on highly-trained technologically-oriented individuals. On the other hand, Latin America and the Caribbean gap premia in those two groups of occupations are widening from other immigrants and regions, showing that immigrants from LAC are no taking advantage of the shift in America's Labor Market towards a more TechnologyDriven market.

15 See table A2 for a list of occupations by category. 


\section{Table 5}

\section{Schooling premium by selected regions and occupation (men immigrants)}

\begin{tabular}{|c|c|c|c|c|c|c|c|c|}
\hline \multirow[t]{2}{*}{ Managerial } & \multicolumn{2}{|c|}{$<=1969$} & \multicolumn{2}{|c|}{$1970-79$} & \multicolumn{2}{|c|}{$1980-89$} & \multicolumn{2}{|c|}{$1990-2010$} \\
\hline & Secondary & Tertiary & Secondary & Tertiary & Secondary & Tertiary & Secondary & Tertiary \\
\hline EAP & $\begin{array}{c}-0.0184 \\
(0.0204)\end{array}$ & $\begin{array}{l}-0.0049 \\
(0.0105)\end{array}$ & $\begin{array}{c}-0.0444 * * \\
(0.0210)\end{array}$ & $\begin{array}{c}0.0138^{* *} \\
(0.0070)\end{array}$ & $\begin{array}{l}-0.0032 \\
(0.0229)\end{array}$ & $\begin{array}{c}0.0098 \\
(0.0071)\end{array}$ & $\begin{array}{l}-0.0403 \\
(0.0360)\end{array}$ & $\begin{array}{c}0.0017 \\
(0.0077)\end{array}$ \\
\hline India & $\begin{array}{c}-0.0586 * * \\
(0.0280)\end{array}$ & $\begin{array}{l}-0.0069 \\
(0.0110)\end{array}$ & $\begin{array}{c}-0.0619 * * \\
(0.0304)\end{array}$ & $\begin{array}{c}0.0100 \\
(0.0072)\end{array}$ & $\begin{array}{l}-0.0252 \\
(0.0301)\end{array}$ & $\begin{array}{c}0.0246 * * * \\
(0.0072)\end{array}$ & $\begin{array}{l}-0.0386 \\
(0.0437)\end{array}$ & $\begin{array}{c}0.0369 * * * \\
(0.0074)\end{array}$ \\
\hline LAC & $\begin{array}{l}-0.0227 \\
(0.0193)\end{array}$ & $\begin{array}{l}-0.0110 \\
(0.0117)\end{array}$ & $\begin{array}{l}-0.0169 \\
(0.0194)\end{array}$ & $\begin{array}{c}-0.0004 \\
(0.0075)\end{array}$ & $\begin{array}{l}-0.0033 \\
(0.0189)\end{array}$ & $\begin{array}{l}-0.0044 \\
(0.0069)\end{array}$ & $\begin{array}{c}-0.0164 \\
(0.0273)\end{array}$ & $\begin{array}{c}0.0001 \\
(0.0074)\end{array}$ \\
\hline Northern Europe & $\begin{array}{c}0.0950 * * * \\
(0.0192)\end{array}$ & $\begin{array}{c}0.0806 * * * \\
(0.0103)\end{array}$ & $\begin{array}{c}0.1081^{* * *} \\
(0.0218)\end{array}$ & $\begin{array}{c}0.0844 * * * \\
(0.0069)\end{array}$ & $\begin{array}{c}0.0986 * * * \\
(0.0226)\end{array}$ & $\begin{array}{c}0.0909 * * * \\
(0.0066)\end{array}$ & $\begin{array}{l}0.0733^{*} \\
(0.0420)\end{array}$ & $\begin{array}{c}0.0601 * * * \\
(0.0068)\end{array}$ \\
\hline Southern Europe & $\begin{array}{c}0.0039 \\
(0.0201) \\
\end{array}$ & $\begin{array}{c}0.0308^{* *} \\
(0.0137) \\
\end{array}$ & $\begin{array}{c}0.0129 \\
(0.0249) \\
\end{array}$ & $\begin{array}{c}0.0443^{* * *} \\
(0.0118)\end{array}$ & $\begin{array}{c}0.0202 \\
(0.0294) \\
\end{array}$ & $\begin{array}{c}0.0656^{* * *} \\
(0.0120)\end{array}$ & $\begin{array}{l}-0.0827^{*} \\
(0.0423)\end{array}$ & $\begin{array}{c}0.0291 * * * \\
(0.0103) \\
\end{array}$ \\
\hline $\begin{array}{l}\text { Observations } \\
\text { R-squared }\end{array}$ & \multicolumn{2}{|c|}{11779} & \multicolumn{2}{|c|}{10781} & \multicolumn{2}{|c|}{$\begin{array}{c}9987 \\
0.2386\end{array}$} & \multicolumn{2}{|c|}{$\begin{array}{c}7777 \\
0.2670 \\
\end{array}$} \\
\hline \multirow[t]{2}{*}{ Professional specialty } & \multicolumn{2}{|c|}{$<=1969$} & \multicolumn{2}{|c|}{ 1970-79 } & \multicolumn{2}{|c|}{$1980-89$} & \multicolumn{2}{|c|}{ 1990-2010 } \\
\hline & Secondary & Tertiary & Secondary & Tertiary & Secondary & Tertiary & Secondary & Tertiary \\
\hline EAP & $\begin{array}{l}-0.0423 \\
(0.0399)\end{array}$ & $\begin{array}{c}0.0087 \\
(0.0055)\end{array}$ & $\begin{array}{c}0.0170 \\
(0.0348)\end{array}$ & $\begin{array}{c}0.0061 \\
(0.0040)\end{array}$ & $\begin{array}{c}0.0695 \\
(0.0478)\end{array}$ & $\begin{array}{c}-0.0024 \\
(0.0043)\end{array}$ & $\begin{array}{l}-0.0321 \\
(0.0559)\end{array}$ & $\begin{array}{l}-0.0031 \\
(0.0042)\end{array}$ \\
\hline India & $\begin{array}{l}-0.0356 \\
(0.0504)\end{array}$ & $\begin{array}{c}0.0181 * * * \\
(0.0057)\end{array}$ & $\begin{array}{c}0.0146 \\
(0.0520)\end{array}$ & $\begin{array}{c}0.0267^{* * *} \\
(0.0039)\end{array}$ & $\begin{array}{c}0.0322 \\
(0.0553)\end{array}$ & $\begin{array}{c}0.0267^{* * *} \\
(0.0044)\end{array}$ & $\begin{array}{l}-0.0213 \\
(0.0800)\end{array}$ & $\begin{array}{c}0.0351^{* * *} \\
(0.0046)\end{array}$ \\
\hline LAC & $\begin{array}{c}-0.1063^{* * *} \\
(0.0360)\end{array}$ & $\begin{array}{c}0.0062 \\
(0.0068)\end{array}$ & $\begin{array}{c}-0.0948 * * * \\
(0.0316)\end{array}$ & $\begin{array}{l}-0.0086^{*} \\
(0.0048)\end{array}$ & $\begin{array}{l}-0.0082 \\
(0.0399)\end{array}$ & $\begin{array}{c}-0.0129 * * * \\
(0.0044)\end{array}$ & $\begin{array}{c}-0.1101^{* *} \\
(0.0482)\end{array}$ & $\begin{array}{c}-0.0177^{* * *} \\
(0.0049)\end{array}$ \\
\hline Northern Europe & $\begin{array}{c}0.0024 \\
(0.0361)\end{array}$ & $\begin{array}{c}0.0150 * * * \\
(0.0058)\end{array}$ & $\begin{array}{l}-0.0069 \\
(0.0361)\end{array}$ & $\begin{array}{c}0.0261^{* * *} \\
(0.0042)\end{array}$ & $\begin{array}{c}0.1074 * * \\
(0.0446)\end{array}$ & $\begin{array}{c}0.0231^{* * *} \\
(0.0044)\end{array}$ & $\begin{array}{c}0.0097 \\
(0.0582)\end{array}$ & $\begin{array}{c}0.0229 * * * \\
(0.0043)\end{array}$ \\
\hline Southern Europe & $\begin{array}{l}-0.0497 \\
(0.0435)\end{array}$ & $\begin{array}{l}-0.0071 \\
(0.0094)\end{array}$ & $\begin{array}{l}-0.0549 \\
(0.0478)\end{array}$ & $\begin{array}{c}0.0257^{* * *} \\
(0.0093)\end{array}$ & $\begin{array}{c}0.1257^{* *} \\
(0.0614)\end{array}$ & $\begin{array}{c}0.0196 * * \\
(0.0080)\end{array}$ & $\begin{array}{c}0.0025 \\
(0.0566)\end{array}$ & $\begin{array}{c}0.0078 \\
(0.0062) \\
\end{array}$ \\
\hline $\begin{array}{l}\text { Observations } \\
\text { R-squared }\end{array}$ & \multicolumn{2}{|c|}{10256} & \multicolumn{2}{|c|}{10253} & \multicolumn{2}{|c|}{$\begin{array}{l}10761 \\
0.1484 \\
\end{array}$} & $\begin{array}{l}113 \\
0.18 \\
\end{array}$ & $\begin{array}{l}50 \\
824\end{array}$ \\
\hline \multirow[t]{2}{*}{ Other white collar } & $<=1$ & 969 & 1970 & $0-79$ & 1980 & $0-89$ & $1990-$ & 2010 \\
\hline & Secondary & Tertiary & Secondary & Tertiary & Secondary & Tertiary & Secondary & Tertiary \\
\hline EAP & $\begin{array}{c}-0.0481^{* * *} \\
(0.0075)\end{array}$ & $\begin{array}{l}-0.0118 \\
(0.0075)\end{array}$ & $\begin{array}{c}-0.0618^{* * *} \\
(0.0081)\end{array}$ & $\begin{array}{c}-0.0209 * * * \\
(0.0048)\end{array}$ & $\begin{array}{c}-0.0583^{* * *} \\
(0.0094)\end{array}$ & $\begin{array}{c}-0.0225^{* * *} \\
(0.0049)\end{array}$ & $\begin{array}{c}-0.0778^{* * *} \\
(0.0119)\end{array}$ & $\begin{array}{c}-0.0199 * * * \\
(0.0051)\end{array}$ \\
\hline India & $\begin{array}{c}-0.0476 * * * \\
(0.0101)\end{array}$ & $\begin{array}{l}-0.0073 \\
(0.0085)\end{array}$ & $\begin{array}{c}-0.0571^{* * *} \\
(0.0107)\end{array}$ & $\begin{array}{c}-0.0446 * * * \\
(0.0057)\end{array}$ & $\begin{array}{c}-0.0621^{* * *} \\
(0.0125)\end{array}$ & $\begin{array}{l}-0.0016 \\
(0.0056)\end{array}$ & $\begin{array}{c}-0.0778 * * * \\
(0.0157)\end{array}$ & $\begin{array}{c}0.0479 * * * \\
(0.0047)\end{array}$ \\
\hline LAC & $\begin{array}{c}-0.0323 * * * \\
(0.0070)\end{array}$ & $\begin{array}{c}-0.0270^{* * *} \\
(0.0084)\end{array}$ & $\begin{array}{c}-0.0524^{* * *} \\
(0.0076)\end{array}$ & $\begin{array}{c}-0.0578 * * * \\
(0.0053)\end{array}$ & $\begin{array}{c}-0.0499 * * * \\
(0.0084)\end{array}$ & $\begin{array}{c}-0.0806 * * * \\
(0.0050)\end{array}$ & $\begin{array}{c}-0.0750^{* * *} \\
(0.0101)\end{array}$ & $\begin{array}{c}-0.0869 * * * \\
(0.0055)\end{array}$ \\
\hline Northern Europe & $\begin{array}{c}0.0502 * * * \\
(0.0080)\end{array}$ & $\begin{array}{c}0.0855 * * * \\
(0.0088)\end{array}$ & $\begin{array}{c}0.0580 * * * \\
(0.0108)\end{array}$ & $\begin{array}{c}0.0559 * * * \\
(0.0070)\end{array}$ & $\begin{array}{c}0.0802 * * * \\
(0.0117)\end{array}$ & $\begin{array}{c}0.0522 * * * \\
(0.0063)\end{array}$ & $\begin{array}{c}0.0195 \\
(0.0187)\end{array}$ & $\begin{array}{c}0.0321 * * * \\
(0.0059)\end{array}$ \\
\hline Southern Europe & $\begin{array}{c}-0.0172 * * \\
(0.0083)\end{array}$ & $\begin{array}{c}0.0429 * * * \\
(0.0119)\end{array}$ & $\begin{array}{c}-0.0221^{*} \\
(0.0117)\end{array}$ & $\begin{array}{c}0.0135 \\
(0.0130)\end{array}$ & $\begin{array}{c}0.0043 \\
(0.0162)\end{array}$ & $\begin{array}{l}-0.0001 \\
(0.0146)\end{array}$ & $\begin{array}{l}-0.0061 \\
(0.0224)\end{array}$ & $\begin{array}{l}-0.0028 \\
(0.0155)\end{array}$ \\
\hline $\begin{array}{l}\text { Observations } \\
\text { R-squared }\end{array}$ & $\begin{array}{l}228 \\
0.2 \\
\end{array}$ & & & & & & & \\
\hline Blue collar & $<=1$ & 969 & 1970 & $0-79$ & 1980 & $0-89$ & $1990-$ & 2010 \\
\hline & Secondary & Tertiary & Secondary & Tertiary & Secondary & Tertiary & Secondary & Tertiary \\
\hline EAP & $\begin{array}{c}-0.0341 * * * \\
(0.0052)\end{array}$ & $\begin{array}{l}-0.0000 \\
(0.0069)\end{array}$ & $\begin{array}{c}-0.0428 * * * \\
(0.0050)\end{array}$ & $\begin{array}{l}-0.0010 \\
(0.0053)\end{array}$ & $\begin{array}{c}-0.0302^{* * *} \\
(0.0069)\end{array}$ & $\begin{array}{c}0.0171^{* * *} \\
(0.0065)\end{array}$ & $\begin{array}{c}-0.0318^{* * *} \\
(0.0107)\end{array}$ & $\begin{array}{c}0.0128 \\
(0.0096)\end{array}$ \\
\hline India & $\begin{array}{c}-0.0405^{* * *} \\
(0.0082)\end{array}$ & $\begin{array}{c}0.0012 \\
(0.0097)\end{array}$ & $\begin{array}{c}-0.0592 * * * \\
(0.0078)\end{array}$ & $\begin{array}{l}-0.0126^{*} \\
(0.0071)\end{array}$ & $\begin{array}{c}-0.0453^{* * *} \\
(0.0105)\end{array}$ & $\begin{array}{c}0.0004 \\
(0.0093)\end{array}$ & $\begin{array}{c}0.0028 \\
(0.0181)\end{array}$ & $\begin{array}{c}0.0316 * * * \\
(0.0113)\end{array}$ \\
\hline LAC & $\begin{array}{c}-0.0343^{* * *} \\
(0.0041)\end{array}$ & $\begin{array}{c}-0.0192 * * \\
(0.0077)\end{array}$ & $\begin{array}{c}-0.0514^{* * *} \\
(0.0036)\end{array}$ & $\begin{array}{c}-0.0237^{* * *} \\
(0.0050)\end{array}$ & $\begin{array}{c}-0.0471 * * * \\
(0.0044)\end{array}$ & $\begin{array}{c}-0.0261^{* * *} \\
(0.0053)\end{array}$ & $\begin{array}{c}-0.0549 * * * \\
(0.0067)\end{array}$ & $\begin{array}{c}-0.0541 * * * \\
(0.0074)\end{array}$ \\
\hline Northern Europe & $\begin{array}{c}0.0434 * * * \\
(0.0047)\end{array}$ & $\begin{array}{c}0.0993 * * * \\
(0.0095)\end{array}$ & $\begin{array}{c}0.0207 * * * \\
(0.0066)\end{array}$ & $\begin{array}{c}0.0802 * * * \\
(0.0098)\end{array}$ & $\begin{array}{c}0.0231^{* * *} \\
(0.0074)\end{array}$ & $\begin{array}{c}0.0930 * * * \\
(0.0098)\end{array}$ & $\begin{array}{c}0.0273 * * \\
(0.0127)\end{array}$ & $\begin{array}{c}0.0772 * * * \\
(0.0128)\end{array}$ \\
\hline Southern Europe & $\begin{array}{c}0.0181^{* * *} \\
(0.0048)\end{array}$ & $\begin{array}{c}0.0302 * * \\
(0.0148)\end{array}$ & $\begin{array}{c}0.0080 \\
(0.0066)\end{array}$ & $\begin{array}{l}0.0384^{*} \\
(0.0217)\end{array}$ & $\begin{array}{c}0.0474 * * * \\
(0.0091)\end{array}$ & $\begin{array}{c}0.0200 \\
(0.0218)\end{array}$ & $\begin{array}{c}0.0111 \\
(0.0230)\end{array}$ & $\begin{array}{c}0.0771^{* * * *} \\
(0.0279) \\
\end{array}$ \\
\hline $\begin{array}{l}\text { Observations } \\
\text { R-squared }\end{array}$ & $\begin{array}{l}269 \\
0.1\end{array}$ & $\begin{array}{l}41 \\
906\end{array}$ & & & & & & \\
\hline
\end{tabular}




\section{Figure 9}

\section{Evolution of secondary schooling premium relative to other immigrants by occupation}

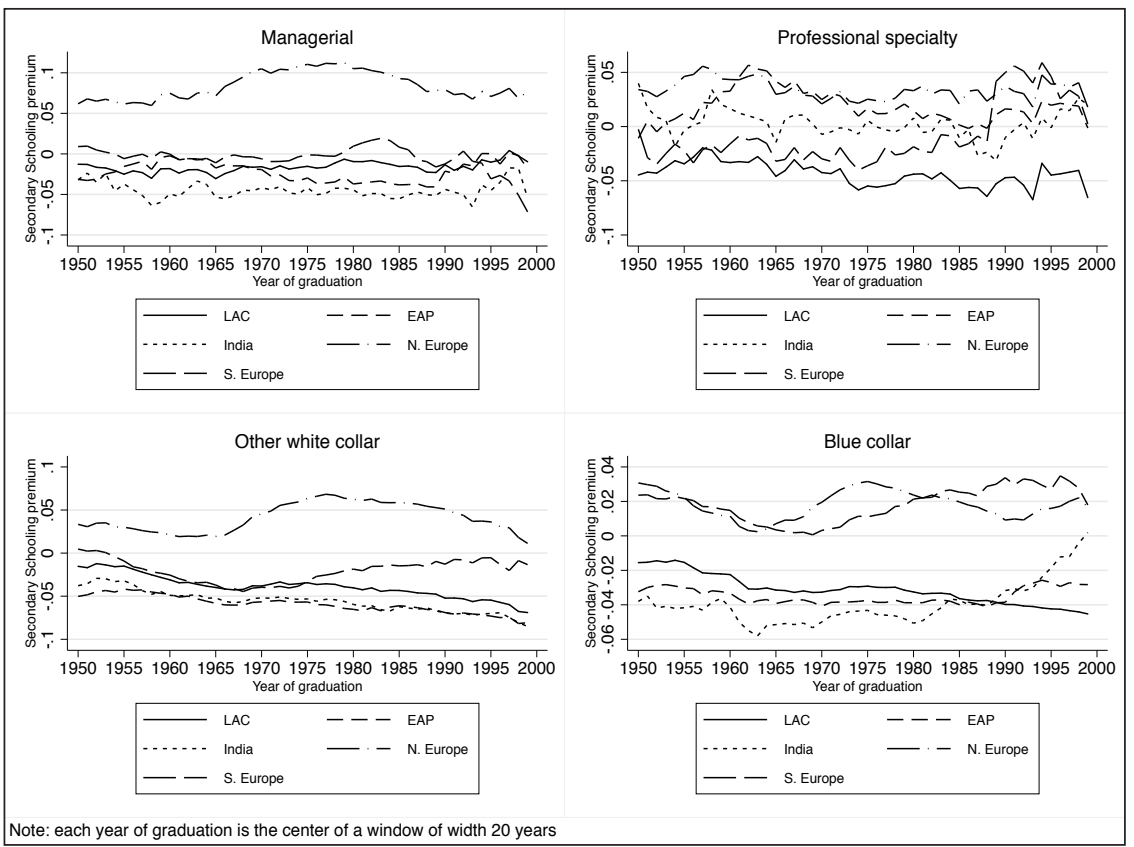

\subsection{Non-parametric matching}

During the half century of our analysis many workers' characteristics may have changed. This section reports the results of an exercise that attempts to control for those changes. For that purpose, we use the matching-on-characteristics approach developed in Nopo (2008) to maintain fixed the distribution of observable characteristics of migrant workers into the US. In this way, for each country of birth, the distribution of characteristics in terms of gender, age and educational level attained is kept fixed and equal to the distribution of characteristics 
Figure 10

\section{Evolution of tertiary schooling premium relative to other immigrants by occupation}

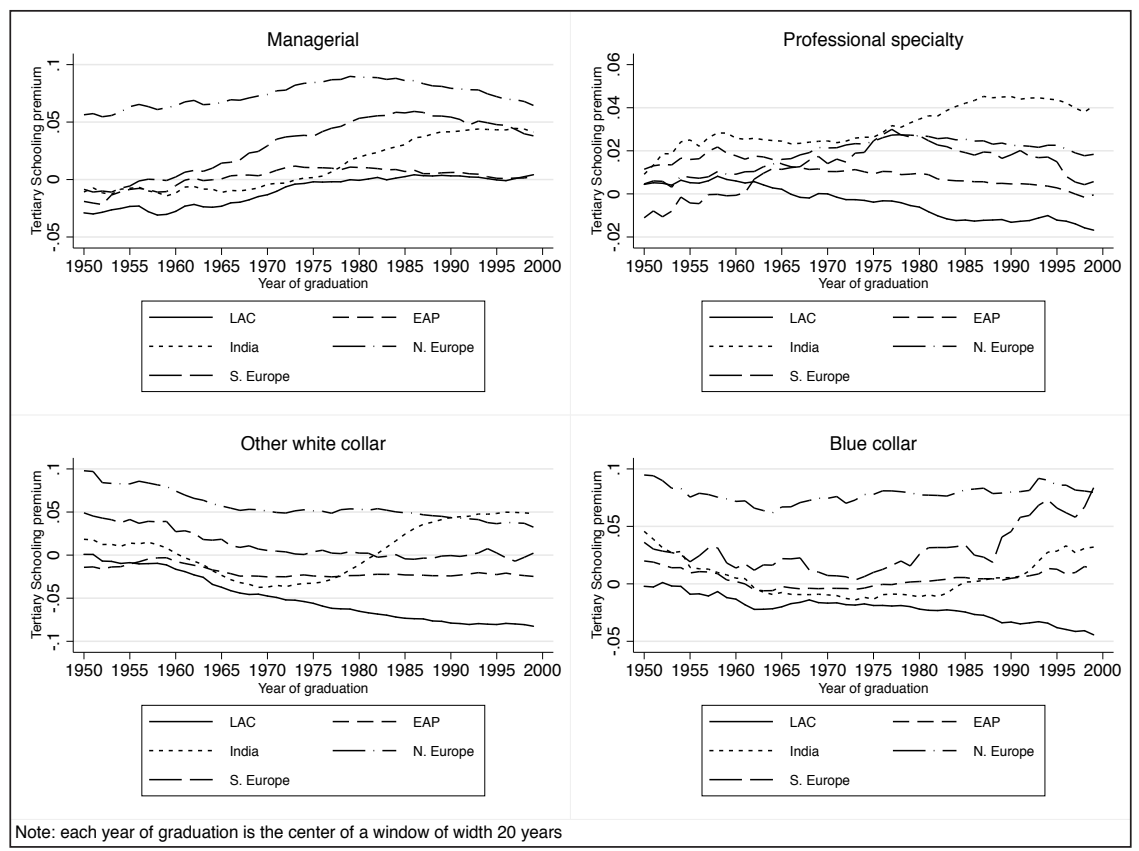

observed for the cohort of migrants who arrived into the US between 1950 and 1959. In this way we generate a counterfactual situation of the type: "how our results would change if the joint distribution of observable characteristics of the immigrants for each country (gender, age and educational level) is kept constant at how it was for migrants who arrived between 1950 and 1959?”

By matching on observables we obtain a new distribution of characteristics for immigrants from recent cohorts that mimic the one for immigrants from the 1950-1959 cohort. (See Nopo, 2008, for further methodological details.) Therefore, we proceed to estimate: 


$$
\begin{gathered}
\ln \left(w_{i j t}\right) w_{\text {matching }}=\left[\alpha+\beta_{1} \mathrm{D}^{*} E D U C_{i}+\beta_{2} E D U C_{i}+\right. \\
\left.\beta_{3} \text { Age }_{i t}+\beta_{4} A_{g e_{i t}}{ }^{2}+\beta_{5} X_{i j t}+\mu_{j t}+\varepsilon_{i t}\right] w_{\text {matching }}
\end{gathered}
$$

where $\mathrm{w}_{\text {matching }}$ denotes the weights after matching (that is, after the differences in the distribution of observable characteristics have vanished).

\section{Table 6}

\section{Schooling premium by selected regions (men immigrants)

\begin{tabular}{|c|c|c|c|c|c|c|c|c|}
\hline & \multicolumn{2}{|c|}{$<=1969$} & \multicolumn{2}{|c|}{ 1970-79 } & \multicolumn{2}{|c|}{$1980-89$} & \multicolumn{2}{|c|}{$1990-2010$} \\
\hline & Secondary & Tertiary & Secondary & Tertiary & Secondary & Tertiary & Secondary & Tertiary \\
\hline EAP & $\begin{array}{c}-0.0544 * * * \\
(0.0097)\end{array}$ & $\begin{array}{c}0.0211^{* * *} \\
(0.0055)\end{array}$ & $\begin{array}{c}-0.0630 * * * \\
(0.0061)\end{array}$ & $\begin{array}{c}0.0075^{* *} \\
(0.0036)\end{array}$ & $\begin{array}{c}-0.0510 * * * \\
(0.0062)\end{array}$ & $\begin{array}{c}0.0061^{* *} \\
(0.0029)\end{array}$ & $\begin{array}{c}-0.0452^{* *} \\
(0.0177)\end{array}$ & $\begin{array}{c}0.0040 \\
(0.0052)\end{array}$ \\
\hline India & $\begin{array}{c}-0.0502^{* *} \\
(0.0214)\end{array}$ & $\begin{array}{c}0.0343 * * * \\
(0.0081)\end{array}$ & $\begin{array}{c}-0.0424^{* *} \\
(0.0174)\end{array}$ & $\begin{array}{c}0.0130 * * \\
(0.0051)\end{array}$ & $\begin{array}{c}-0.0672 * * * \\
(0.0225)\end{array}$ & $\begin{array}{c}0.0340 * * * \\
(0.0033)\end{array}$ & & $\begin{array}{c}0.0484 * * * \\
(0.0056)\end{array}$ \\
\hline LAC & $\begin{array}{c}-0.0225^{* * *} \\
(0.0060)\end{array}$ & $\begin{array}{l}0.0146 * \\
(0.0080)\end{array}$ & $\begin{array}{c}-0.0534 * * * \\
(0.0042)\end{array}$ & $\begin{array}{c}-0.0230 * * * \\
(0.0039)\end{array}$ & $\begin{array}{c}-0.0446 * * * \\
(0.0047)\end{array}$ & $\begin{array}{c}-0.0348^{* * *} \\
(0.0031)\end{array}$ & $\begin{array}{c}-0.0499 * * * \\
(0.0109)\end{array}$ & $\begin{array}{c}-0.0346 * * * \\
(0.0056)\end{array}$ \\
\hline Northern Europe & $\begin{array}{c}0.0406 * * * \\
(0.0066)\end{array}$ & $\begin{array}{c}0.0660 * * * \\
(0.0052)\end{array}$ & $\begin{array}{c}0.0466 * * * \\
(0.0065)\end{array}$ & $\begin{array}{c}0.0712^{* * *} \\
(0.0037)\end{array}$ & $\begin{array}{c}0.0733^{* * *} \\
(0.0082)\end{array}$ & $\begin{array}{c}0.0845^{* * *} \\
(0.0034)\end{array}$ & $\begin{array}{c}0.0557 * * \\
(0.0269)\end{array}$ & $\begin{array}{c}0.0681^{* * *} \\
(0.0053)\end{array}$ \\
\hline Southern Europe & $\begin{array}{l}-0.0039 \\
(0.0067)\end{array}$ & $\begin{array}{c}0.0296 * * * \\
(0.0084) \\
\end{array}$ & $\begin{array}{c}0.0004 \\
(0.0069)\end{array}$ & $\begin{array}{c}0.0453^{* * *} \\
(0.0079)\end{array}$ & $\begin{array}{c}0.0422 * * * \\
(0.0105)\end{array}$ & $\begin{array}{c}0.0603 * * * \\
(0.0070)\end{array}$ & $\begin{array}{l}-0.0092 \\
(0.0334)\end{array}$ & $\begin{array}{c}0.0429 * * * \\
(0.0094)\end{array}$ \\
\hline $\begin{array}{l}\text { Observations } \\
\text { R-squared }\end{array}$ & \multicolumn{2}{|c|}{62101} & \multicolumn{2}{|c|}{57182} & \multicolumn{2}{|c|}{48095} & \multicolumn{2}{|c|}{12274} \\
\hline
\end{tabular} (With weights after matching)}

As table 6 and figures 11 and 12 show, the main results stand. Immigrants from Latin America and the Caribbean show the lowest premia both for secondary and tertiary, but particularly for tertiary where the premia for immigrants from LAC is clearly lagging behind. Besides, the remarkable improvement in premia for immigrants from India still stand. 


\section{Figure 11}

Evolution of secondary schooling premium relative to other immigrants (With weights after matching)

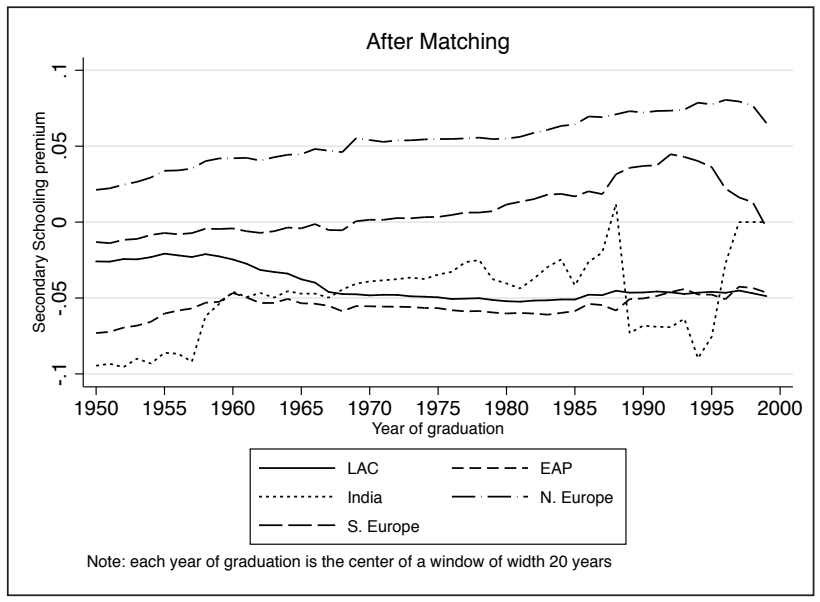

Figure 12

Evolution of tertiary schooling premium relative to other immigrants (With weights after matching)

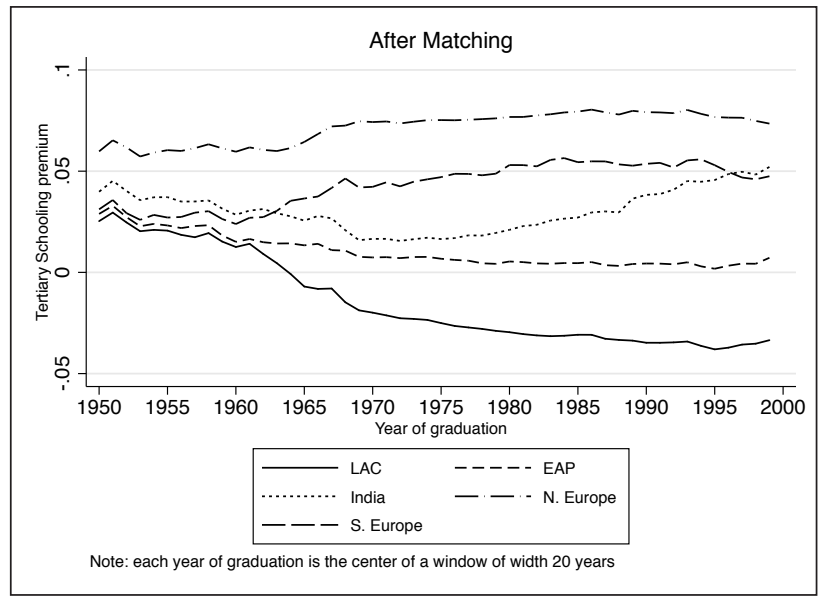





\section{CONCLUSIONS}

In this paper we show proxy evidence that the schooling premia in Latin America have been steadily low for the last 50 years. Besides, these results stand after controlling for selective migration in different ways. This contradicts the popular belief in policy circles that the education quality of the region has deteriorated in recent years. However, Latin America and the Caribbean is a very heterogeneous region and there are certainly some differences among countries. Southern cone countries have better premia, particularly at the tertiary level. In Central America, Costa Rica and Panama stand out over their neighbors and Cuba show a significant improvement particularly at secondary during the period of analysis. All in all, the overall picture for the region shows little room for optimism and should be caused of concern.

The shift from a labor force composed of mostly manual laborers to mostly white collar and service workers occurred in the US a few decades ago. In this context, it seems that immigrants from LAC are not prepared enough and hence not taking advantage of the technology-driven shift. As a result, there is the concern that education systems in the region are failing to prepare students for the workforce and to compete in this context of rapid changes and global economy.

In contrast, schooling premium in India shows an impressive improvement in recent decades, especially at the tertiary level. This goes in line with the idea that the selective migration of Indian workers to the US emphasized on highly-trained technologically-oriented individuals, 
showing that least for a selected group, the education system in India is providing some skills that have been highly rewarded in the US for the last two decades. 
REFERENCES

Barro, Robert J., and Jong-Wha Lee (2010). A new data set of educational attainment in the world, 1950-2010. NBER Working Paper, 15902. Cambridge, MA: National Bureau of Economic Research.

Banerjee, Abhijit V., and Esther Duflo (2005). Growth theory through the lens of development economics. In Philippe Aghion \& Steven Durlauf (Eds.). Handbook of Economic Growth Vol. 1 A (pp. 473552). North Holland.

Borjas, George J. (1987). Self-selection and the earnings of immigrants. The American Economic Review, 77(4), 531-553.

Borjas, George J. (1992). Ethnic capital and intergenerational mobility. Quarterly Journal of Economics, 107(1), 123-150.

Borjas, George J. (1999). The skills of immigrants. In George J. Borjas. Heaven's door: Immigration policy and the American economy. New Jersey: Princeton University Press.

Borjas, George J., and Rachel M. Friedberg (2009). Recent trends in the earnings of new immigrants to the United States. NBER Working Paper, 15406). Cambridge, MA: National Bureau of Economic Research. Retrieved from http://www.nber.org/papers/w15406

Bratsberg, Bernt, and James F. Ragan Jr. (2002). The impact of hostcountry schooling on earnings: a study of male immigrants in the United States. Journal of Human Resources, 37(1), 63-105 
Bratsberg, Bernt, and Dek Terrell (2002). School quality and returns to education of US immigrants. Economic Inquiry, 40(2), 177-198.

Chiswick, Barry R. (2000). Are immigrants favorably self-selected?: an economic analysis. In: Caroline B. Brettell and James F. Hollifield (Eds.). Migration theory: talking across disciplines (pp. 61-76). New York: Routledge.

Colclough, Christopher; Geeta Kingdon, and Harry Patrinos (2010). The changing patterns of wage returns to education and its implications. Development Policy Review, 28(6):733-47.

Hanushek, Eric A., and Dennis D. Kimko (2000). Schooling, laborforce quality, and the growth of nations. American Economic Review, 90(5), 1184-1208.

Hanushek, Eric A., and Ludger Woessmann (2007). The role of education quality for economic growth. World Bank Policy Research Working Paper, 4122. Retrieved from http://papers.ssrn.com/ abstract $=960379$

Hanushek, Eric A., and Ludger Woessmann. (2012a). Do better schools lead to more growth?: cognitive skills, economic outcomes, and causation. Journal of Economic Growth, 17(4), 267-321. Retrieved from http://EconPapers.repec.org/RePEc:kap:jecgro:v: 17:y:2012:i:4:p:267-321

Hanushek, Eric A., and Ludger Woessmann (2012b). Schooling, educational achievement, and the Latin American growth puzzle. Journal of Development Economics, 99(2), 497-512, 2012.

Harmon, Colm; Hessel Oosterbeek, and Ian Walker (2003). The returns to education: nicroeconomics. Journal of Economic Surveys, $17(2), 115-56$. 
Heckman, James; Lance J. Lochner, and Petra E. Todd (2003). Fifty years of Mincer earnings regressions. Retrieved from http://athena. sas.upenn.edu/petra/papers/llmincer.pdf

Jaeger, David A. (1997). Reconciling educational attainment questions in the CPS and the census. Monthly Labor Review, 120(8), 36-40.

Jaeger, David A. (2003). Estimating the returns to education using the newest current population survey education questions. Economics Letters, 78(3), 385-394.

LaLonde, Robert J., and Robert H. Topel (1991). Labor market adjustments to increased immigration. In John M. Abowd and Richard B. Freeman (Eds.). Immigration, trade, and the labor market (pp. 167-199). Chicago: University of Chicago Press.

Lee, Everett S. (1966). A theory of migration. Demography, 3(1), 47-57.

Mincer, Jacob (1958). Investment in human capital and personal income distribution. Journal of Political Economy, 66(4), 281-302.

Mincer, Jacob (1974). Schooling, experience and earnings. New York: Columbia University Press for the National Bureau of Economic Research.

Montenegro, Claudio E., and Harry A. Patrinos (2014). Comparable estimates of returns to schooling around the world. World Bank Policy Research Working Paper, 7020 Retrieved from https://papers. ssrn.com/sol3/papers.cfm?abstract_id $=2491933$

Nopo, Hugo (2008). Matching as a tool to decompose wage gap. Review of Economics and Statistics, 90(2), 290-299.

Psacharopoulos, George (1972). Rates of return on investment in education around the world. Comparative Education, 16(1), 54-67.

Psacharopoulos, George (1973). Returns to education: an international comparison. Amsterdam, San Francisco: Elsevier and Jossey-Bass. 
Psacharopoulos, George (1985). Returns to education: a further international update and implications. Journal of Human Resources, 20(4), 583-604.

Psacharopoulos, George (1989). Time trends of the returns to education: cross-national evidence. Economics of Education Review, 8(3), 225-31.

Psacharopoulos, George (1994). Returns to education: a global update. World Development, 22(9), 1325-43.

Psacharopoulos, George (1995). The profitability of investment in education: concepts and methods. Washington, DC: World Bank.

Psacharopoulos, George, and Layard, R., (2012). Rates of return to investment in education: an international comparison. Washington, DC: World Bank, Human Development Network. Processed.

Psacharopoulos, George, and Harry A. Patrinos (2004). Returns to investment in education: a further update. Education Economics, 12(2), 111-34.

Psacharopoulos, George, and Harry A. Patrinos (2014). Returns to investment in education: a review and further update. Washington, DC: World Bank. Processed. 


\section{APPENDIX}

\section{Figure A1}

Years of education, US immigrants (US census)

vs Population of origin (Barro and Lee)

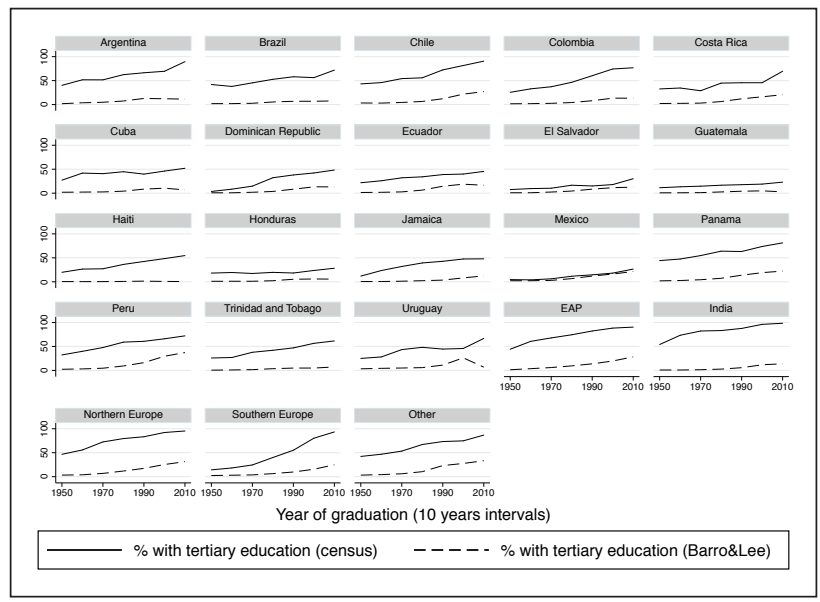

Figure A2

$\%$ of immigrants by occupation

(Professional specialty vs Blue collar)

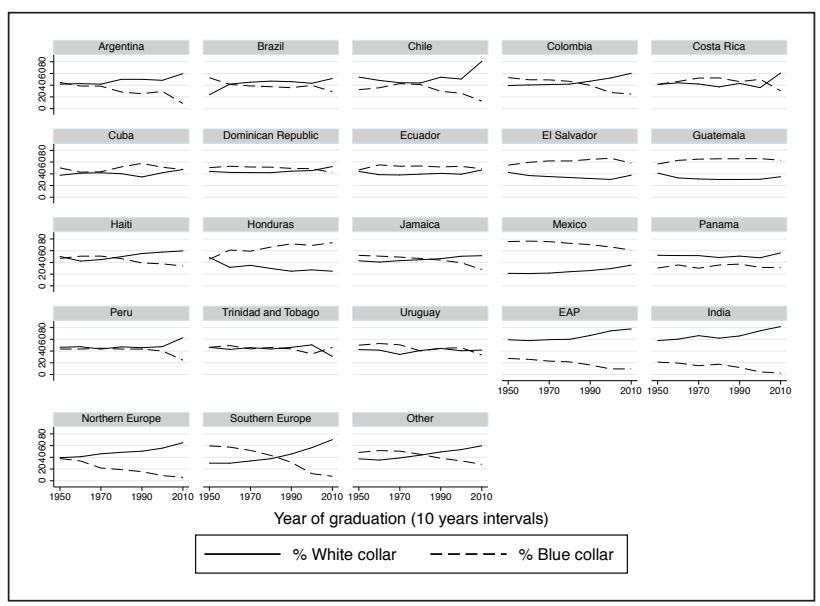


Figure A3

\section{Waves of immigrants by country ( 5 years intervals)}

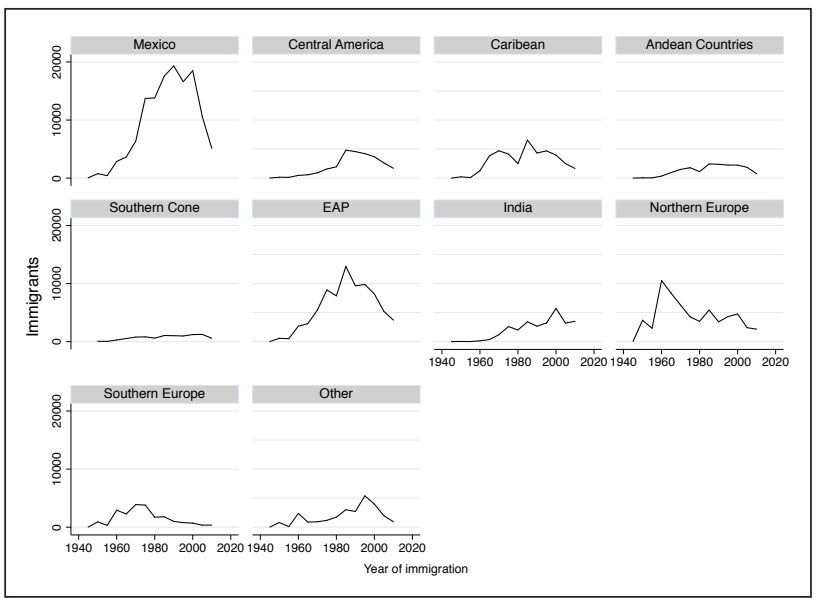

\section{Table A1}

\section{List of countries by region}

\begin{tabular}{cccc}
\hline \hline \multicolumn{3}{c}{ List of countries by region } \\
\hline \hline EAP & N. Europe & S. Europe & $\begin{array}{c}\text { Former Soviet } \\
\text { Republics }\end{array}$ \\
\hline China & Austria & Greece & Albania \\
Hong Kong & Belgium & Italy & Armenia \\
Indonesia & Denmark & Portugal & Bulgaria \\
Japan & Finland & Spain & Czech Rep. \\
Korea, Rep. & France & & Estonia \\
Macao-China & Germany & & Hungary \\
Malaysia & Iceland & & Latvia \\
Philippines & Ireland & & Lithuania \\
Singapore & Liechtenstein & Macedonia \\
Taiwan & Luxembourg & Moldova \\
Thailand & Netherlands & Poland \\
& Norway & Romania \\
& Sweden & Russian Fed. \\
& Switzerland & Slovak Rep. \\
& UK & \\
\hline \hline
\end{tabular}




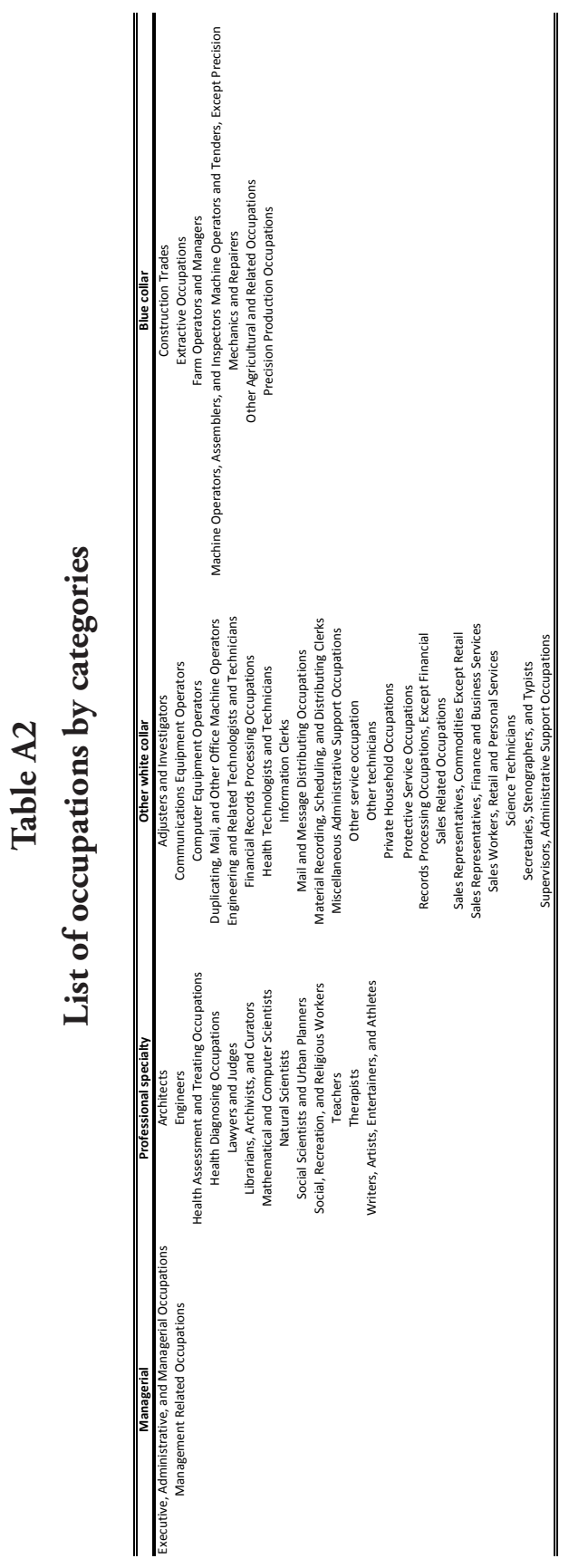


How do Latin American migrants in the U.S.

stand on schooling premium?

What does it reveal about education

quality in their home countries?

se terminó de editar en el

mes de setiembre del 2017. 